\title{
AUGUSTO COMTE E O "POSITIVISMO" REDESCOBERTOS
}

\author{
Gustavo Biscaia de Lacerda
}

\begin{abstract}
RESUMO
Neste ensaio abordamos algumas pesquisas que, nos últimos dez anos ou mais, têm recuperado a obra do fundador do Positivismo, Augusto Comte. Essa recuperação consiste em perceber os trabalhos de Comte em sua inteireza e a partir de sua lógica interna, enfatizando em particular a sua segunda grande obra, o Système de politique positive (1851-1854), e as suas contribuições para a reflexão social e política contemporânea. A fim de tornar inteligivel a novidade dessas novas pesquisas, apresentamos uma das narrativaspadrão a respeito de Comte e do Positivismo - no caso, a partir dos escritos de Anthony Giddens -; além disso, fazemos uma discussão sobre o significado da palavra "Positivismo" e as várias correntes teóricas subsumidas em tal expressão.
\end{abstract}

PALAVRAS-CHAVE: Positivismo; Augusto Comte; Système de politique positive; Anthony Giddens; Círculo de Viena.

FÉDI, Laurent. 2008. Comte. São Paulo: Estação Liberdade.

GRANGE, Juliette. 1996. La philosophie d'Auguste Comte. Science, politique, religion. Paris : PUF.

TISKI, Sérgio. 2007. A questão da moral em Augusto Comte. Londrina: UEL.

\section{INTRODUÇÃO}

É mais ou menos consensual no âmbito das Ciências Sociais que a palavra "Positivismo" tem um significado negativo, assim como que já possuiu um significado positivo. Acompanhar a mudança de valoração dessa palavra é historiar uma parte importante da história das Ciências Sociais no Brasil e no mundo ao longo do século XX e início do século XXI. Por outro lado, o conteúdo desse "Positivismo" não é algo consensual nem muito menos preciso, variando desde a equivalência à reação política da burguesia (com Lênin) até à razão instrumental que desumaniza (com a Escola de Frankfurt); no Brasil, também são freqüentes as afirmações de que "os positivistas" estiveram na raiz do regime militar de 1964. De lambujem, afirma-se que o Positivismo Jurídico, o Comportamentalismo psicológico, o Positivismo na História são variações, ou melhor, aplicações do Positivismo original, vinculado à Filosofia e à Sociologia.

Em quaisquer dessas hipóteses, a origem do "Positivismo" é atribuída ao francês Augusto Comte (1798-1857), autor dos famosos Système de philosophie positive (1830-1842) e Cathéchisme positiviste (1852) e dos menos famosos Système de politique positive (1851-1854), Appel aux conservateurs (1855) e Synthèse subjective (1856), além de algumas outras publicações menores e de extensa correspondência. A relação que se estabelece entre a filosofia do francês Comte - chamada de "filosofia positiva" ou "Positivismo" - e as várias correntes denominadas de "Positivismo" baseia-se em diversas possibilidades: a primeira, claro, é a identidade de nome em diversas situações; em seguida, alguns vínculos históricos (teóricos e políticos) entre eles; por fim, mera extensão ou ampliação de sentido. Além disso, a crer em alguns abalizados pesquisadores da história da Sociologia - pensamos em Anthony Giddens -, há mais continuidades que rupturas entre uma forma e outra, sendo possível caracterizar o segundo como um prenúncio do primeiro.

Essa caracterização é tanto mais incorreta quanto a influência exercida pelo "Positivismo" "filosófico" no Brasil foi enorme: basta pensar na constante referência ao lema da bandeira nacional, o "Ordem e Progresso". Ora, passar de uma influência tal que permitiu a inscrição no pavilhão

Rev. Sociol. Polít., Curitiba, v. 17, n. 34, p. 319-343, out. 2009 
nacional do lema do "Positivismo" "filosófico" para a confusão corrente e a subsunção dessa "variedade" de "Positivismo" ao "intelectual" revela muito não apenas dos hábitos intelectuais brasileiros quanto indica os descaminhos da história das Ciências Sociais e da História das Idéias, de modo geral, ao longo do século XX.

As vinculações indicadas acima constituem uma sugestão teórica - uma hipótese de pesquisa -, que começaria com a leitura do texto original de Comte e avançaria pelas diversas correntes auto ou heterodenominadas de "positivistas", passando pelos críticos do "Positivismo". Esse percurso não apresenta nenhuma grande inovação metodológica, consistindo apenas no exame das perspectivas teóricas e metodológicas de uma extensa literatura filosófica e sociológica: todavia, é curioso que ele não seja realizado, sendo mesmo desprezado. Um passar de olhos em parte importante da literatura teórica das Ciências Sociais contenta-se 1) em estabelecer a relação entre Comte e os demais "positivismos" a partir da coincidência de nomes e 2) em repetir lugares-comuns a respeito do "Positivismo" (em particular com um juízo de valor negativo).

Embora tais relatos, de boa ou de má-fé, possam multiplicar-se bastante, é digno de nota que diversos pesquisadores, em vários países, têm investigado diretamente a obra de Comte e chegado à conclusão simples de que a maior parte das relações entre o Positivismo comtiano e os "positivismos" atuais consiste apenas em coincidência terminológica.

Neste ensaio bibliográfico trataremos de algumas das mais representativas dessas pesquisas que recuperam o pensamento original de Comte: de Laurent Fédi, Comte (2008); de Juliette Grange, La philosophie d'Auguste Comte. Science, politique, religion (1996), e, de Sérgio Tiski, $A$ questão da religião em Augusto Comte (2008). Preocupados com questões diversas mas coincidindo em aspectos importantes, esses livros caracterizam-se pelo fato de tomarem como objeto de análise o pensamento de Comte em si mesmo, sem deixarem de apresentar diálogos com questões atuais e sem deixarem de lado perspectivas "críticas".

"Recuperar" o pensamento de Comte é importante por outro motivo, além de fazer justiça ao fundador da Sociologia em pesquisas de Teoria
Política e Social. Considerando que o grande arquiinimigo de várias das principais correntes teóricas nas Ciências Sociais é, precisamente, o "Positivismo", recuperar e discutir o pensamento do próprio Comte é participar de maneira mais adequada, porque mais qualificada, das polêmicas teórico-metodológicas e políticas contemporâneas. Além disso, retirada a extensa camada crítica sobreposta à obra comtiana, é possível perceber que, de fato, essa obra apresenta elementos efetivos para os debates teóricos, metodológicos e políticos atuais.

Dessa forma, antes de discutirmos os livros indicados acima, é necessário examinarmos duas outras questões, intimamente relacionadas: 1) quais e o que são os "positivismos"? 2) Do que o "Positivismo" é acusado? Essas questões não são secundárias; considerando que desde há algumas décadas o "Positivismo" é "outro" teórico contra o qual por assim dizer todos batem-se, variados sentidos do "Positivismo" produzem variadas implicações.

Este artigo terá a seguinte estrutura. Como o presente tema é a recuperação da obra de Comte, em um primeiro momento examinaremos algumas formas usuais de abordá-lo nas Ciências Sociais - em particular, na obra de Anthony Giddens, que apresenta um caráter paradigmático a respeito. $\mathrm{O}$ exame das exposições de Giddens servirá como fio condutor para uma outra discussão: o exame das variedades do "Positivismo", ou seja, a determinação do que se entende por essa palavra nos debates das Ciências Sociais. Esse procedimento facilitará a compreensão e a avaliação de algumas das recentes obras que têm recuperado o pensamento comtiano; por fim, faremos alguns conclusões gerais.

\section{UMANTIPOSITIVISTA PARADIGMÁTICO: GIDDENS}

Como indicamos acima, não é novidade que a palavra "Positivismo" atualmente carrega um valor semântico bastante negativo. Entre a confusão terminológica a respeito da palavra "Positivismo" e a crítica mais ou menos informada a respeito de Comte, várias são as correntes teóricas que se encarrega(ra)m de combatê-lo, a partir das mais variadas perspectivas, entre as quais podemos citar o marxismo, o pós-modernismo, a Sociologia Compreensiva. Como é evidente, cada uma delas mobiliza diferentes pressupostos filo- 
sóficos, a partir de suas preocupações políticas e intelectuais, o que resultaria em discussões muito maiores das que podemos, no espaço de um artigo, realizar.

Ainda assim, a tarefa impõe-se; cumpre examinar alguns dos argumentos sobre Comte nas apresentações críticas a seu respeito. A fim de facilitar, uma exposição sistemática da história da Sociologia, informada por um projeto teóricometodológico, é o que nos interessa; assim, para os fins desta discussão, escolhemos Anthony Giddens, autor de inúmeras obras de referência em Teoria Social e em história da Sociologia. Certamente esse famoso sociólogo não é o único que comete os erros que indicaremos; além disso, não pretendemos negar a importância de várias de suas pesquisas nem, por outro lado, torná-lo uma espécie de bode expiatório teórico; contudo, sendo ele o autor da atual narrativa-padrão da história da Sociologia (segundo suas próprias palavras: GIDDENS \& PIERSON, 1998, p. 45), autor de numerosos manuais ou livros em que aborda o conjunto das teorias sociológicas e políticas e, por fim, devido ao caráter sistemático dos erros sobre Comte (e o "Positivismo") que comete e tendo várias de suas objeções repetidas por outras escolas sociológicas, vale a pena elegê-lo como exemplar.

Com uma extensa obra, para os nossos fins podemos simplificadamente afirmar que Giddens possui livros de história da Teoria Social e livros dedicados às suas próprias elaborações sociológicas; são principalmente os primeiros os que nos interessam, em particular Giddens (1985; 1998; 2000). Escritos mais ou menos na mesma época, esses relatos têm as características de 1) basearem-se na leitura de poucas obras de Comte, 2) usarem largamente opiniões de segunda mão (em particular, Durkheim e Stuart Mill), 3) simplesmente desconsiderar os argumentos do próprio Comte, 4) de modo a poder encaixar forçadamente Comte em categorias que Giddens deseja combater.

\section{II.1. Comte como promotor da tecnologia social não-reflexiva}

Tomemos, por exemplo, o pequeno manual Sociology - A Brief but Critical Introduction (GIDDENS, 1982). As referências a Comte ocupam quatro páginas (idem, p. 12-15), em que Giddens segue este percurso: inicialmente, afirma que Comte foi um dos pensadores do século XIX que, impressionado com o desenvolvimento das ciências naturais em sua época, decidiu adotar os procedimentos dessas mesmas ciências para estudar a sociedade; essa proposta, além disso, seria movida por um desejo similar de aplicação prática dos conhecimentos científicos, resumido na fórmula "prévoir pour pouvoir" ("prever para poder"). A metodologia por assim dizer "naturalística" seria caracterizada pela busca de leis naturais (sociais) e foi posteriormente retomada e formulada na regra durkheimiana de "conceber os fatos sociais como coisas" (idem, p. 1213). Em seguida, Giddens rejeita a aproximação das ciências sociais às ciências naturais por duas ordens de motivos: 1) "we cannot approach society, or 'social facts', as we do objects or events in the natural world, because societies only exist in so far as they are created and re-created in our own actions as human beings. [...] We have to grasp what I would call the double involvement of individuals and institutions: we create society at the same time as we are created by it" (idem, p. 13-14; grifos no original); 2) "[...] the practical implications of sociology are not directly parallel to the technological uses of science, and cannot be. [...] As human beings, we do not just live in history; our understanding of history is an integral part of what history is, and what it may become. This is why we cannot be content with Comte's idea of Prévoir pour pouvoir, seen as social technology" (idem, p. 14-15)1. Em outras palavras, as suas objeções consistem em, por um lado, afirmar a particularidade das Ciências Sociais em relação às Ciências Naturais via reflexividade do ser humano e, por outro lado, que essa

\footnotetext{
1 Tradução livre dos dois trechos: 1) "não podemos abordar a sociedade, ou os 'fatos sociais', como fazemos com objetos ou eventos do mundo natural, pois as sociedades somente existem na medida em que elas são criadas e recriadas por nossas próprias ações como seres humanos. [...] Nós temos que adotar o que eu chamaria de duplo envolvimento de indivíduos e instituições: criamos a sociedade ao mesmo tempo que somos criados por ela"; 2) "as implicações práticas da Sociologia não são diretamente paralelas aos usos tecnológicos da ciência e não podem ser. [...] Como seres humanos, nós não vivemos simplesmente na história; nosso entendimento da história é uma parte integral do que a história é e do que ela pode tornar-se. É por isso que não podemos contentarmo-nos com a idéia de Comte de Prévoir pour pouvoir, vista como tecnologia social".
} 
reflexividade não permite uma "tecnologia social" semelhante à engenharia (que é uma forma de "tecnologia física") 2 .

Pois bem: ambas as objeções são incorretas. Não que sejam erradas em si, mas é incorreto atribuí-las a Augusto Comte, que foi muito claro a seu respeito: por um lado, o caráter reflexivo do ser humano foi desde o início afirmado por ele e, no fundo, a lei dos três estados pressupõe-na; aliás, o caráter específico do ser humano em relação aos outros animais consiste, acima de tudo, em seu caráter histórico, que não é dado simplesmente pela acumulação de "materiais" geração após geração, mas pela reflexividade de cada geração a respeito das anteriores $\mathrm{e}$ - algo fundamental para as discussões sociais contemporâneas - também a respeito das vindouras.

Por outro lado, a Sociologia existe para ter fins práticos. Esses fins "práticos" são, por um lado, intelectuais e morais: ter uma compreensão da realidade (cósmica e social) é importante para a harmonia mental de cada indivíduo; por outro lado, os fins "práticos" são políticos: para Comte, o conhecimento elaborado pelos sociólogos deve ser aplicado politicamente sob a forma de conselhos práticos, não de engenharia social. A divisão entre os poderes Temporal e Espiritual é o maior resultado disso: o poder Temporal - grosso modo, o Estado - deve conhecer a sociedade para saber como lidar com ela: por exemplo, respeitando as famílias, respeitando as várias tradições, permitindo as várias liberdades, em particular as de pensamento e de expressão etc. Por outro lado, o poder Espiritual pode ser também chamado - literalmente - de "sociedade civil" e consiste em uma série de órgãos formuladores da opinião pública, capaz de orientar a ação do Estado e, acima de tudo, de estabelecer limites para ela (o que inclui a (des)legitimação). O que é importante assinalar é que os sociólogos (ou, sendo mais correto a respeito da terminologia comtiana, os sacerdotes) devem permanecer no poder Espiritual e não par-

2 Um pouco adiante ele comenta que "[...] sociological analysis teaches sobriety. For although knowledge may be an important adjunct to power, it is not the same as power. And our knowledge of history is always tentative and incomplete" (GIDDENS, 1982, p. 15) (“[...] a análise sociológica ensina a sobriedade. Pois embora o conhecimento possa ser um importante adjunto do poder, ele não é a mesma coisa que o poder. E o nosso conhecimento da história é sempre tentativo e incompleto"). ticipar do poder Temporal: essa restrição não foi feita no sentido de tornar o Estado incompetente ou irresponsável, mas para que os formuladores da opinião pública permaneçam como formuladores da opinião pública, sem confundirem as opiniões sob sua responsabilidade com projetos de tomada do poder - o que, não raramente, podem tornar-se imposição da opinião e censura; uma outra possibilidade da imposição política do saber sociológico são as tecnocracias ${ }^{3}$ - ou, nos termos de Comte, a "pedantocracia"4.

\section{II.2. A retórica da loucura}

Vejamos outro texto de Giddens: "Augusto Comte e o Positivismo", publicado no Brasil em 2000 (GIDDENS, 2000), mas consistindo de fato na republicação de um artigo de 1982. Esse artigo de pouco mais de 11 páginas pretende fazer uma apresentação geral da importância teórica de Comte, ajuntando aos comentários propriamente teóricos algumas observações biográficas relevantes. Cumpre reconhecermos desde já um argumento, na verdade mais uma pequena indicação, bastante iluminadora e até simpática de Giddens a respeito da obra de Comte: a contraposição estilística das duas grandes obras comtianas - o Système de philosophie positive ${ }^{5}(1830-1842)$ e o Système de politique positive (1851-1854) ${ }^{6}-\mathrm{re}-$ vela uma alteração fundamental. Enquanto a

3 Jean Lacroix (2003, p. 101) compreendeu esse aspecto do pensamento comtiano, ao comentar com clareza e simplicidade que "sua [de Comte] concepção de poder Espiritual afastava-o [...] de qualquer tendência tecnocrática" (LACROIX, 2003, p. 101).

4 Uma das conseqüências do caráter sistêmico do pensamento comtiano é que, embora em cada capítulo de suas obras ele tratasse em particular de determinadas questões, essas mesmas questões eram discutidas sob outras perspectivas em outros capítulos, dedicados a outros temas; assim, não apenas a quantidade de citações possíveis para cada tema é enorme como a complexidade das perspectivas também é grande - o que torna a apresentação de suas idéias uma tarefa sempre exigente. Essa constatação é feita por todos os especialistas no pensamento comtiano (cf., por exemplo, GRANGE, 1996; LACROIX, 2003; GANE, 2006; FÉDI, 2008).

5 Originalmente chamado de Cours de philosophie positive, foi alterado para "Système" em 1848 (cf. COMTE, 1957, p. 3).

6 Para simplificar a redação, adotaremos as formas simplificadas de "Philosophie" para referirmo-nos ao Système de philosophie positive e de "Politique" para as referências ao Système de politique positive. 
Philosophie foi redigida em um estilo sóbrio e altamente impessoal, embora a vida pessoal e profissional de Comte estivesse profundamente atribulada, a Politique foi redigida de maneira pessoal e "apaixonada", indicando uma grande alteração pessoal e profissional e, do ponto de vista teórico, uma inflexão importante (GIDDENS, 2000, p. 223). O curioso, quase chocante, é que essa indicação notável é uma exceção em um artigo profundamente antipático; mas como ninguém é obrigado a ter simpatia por ninguém, a questão importante é outra: a antipatia de Giddens é "justificada" por deturpações e más-interpretações reiteradas.

Comecemos por um mito bastante difundido: a "loucura" de Comte. Giddens fala em "vida desregrada" (idem, p. 217), "períodos de loucura" (no plural) (idem, p. 218), "estranhos excessos" da Politique (idem, p. 221), "decadência melancólica de um grande intelecto" (ao referir-se novamente à Politique) (Stuart Mill apud GIDDENS, 2000 , p. 223). Essas quatro observações - devidamente feitas sem referências bibliográficas causam a profunda impressão de que a obra de Comte, em particular a de sua fase mais madura, foi o resultado da especulação de um lunático. Isso é um recurso retórico próximo ao sofisma ad hominem, em que a argumentação teórica e empírica é substituída pela crítica ao autor; além disso, esse procedimento é particularmente especioso, porquanto inúmeros pensadores e teóricos das Ciências Sociais foram "loucos", "desregrados", mau-caracteres ou simplesmente tiveram sérios problemas emocionais e psicológicos. Vejamos alguns: o atualmente tão festejado Friedrich Nietzsche era louco ou catatônico, alternando fases mais ou menos lúcidas a longos períodos anormais; Karl Marx tinha esposa e amante e estuprava ambas, além de difundir mentiras a respeito de seus inimigos políticos para desmoralizá-los 7 ; Max Weber teve um colapso nervoso e desde cerca de 1900 até sua morte, em 1920, esteve incapaz de lecionar oficialmente (embora extra-oficialmente tenha lecionado em diversas instituições do mundo germanófono); John Stuart Mill passou por uma severa depressão no meio de sua carreira intelec-

\footnotetext{
7 Referências úteis sobre a biografia de Marx podem ser encontradas nas obras dos anarquistas, adversários políticos e teóricos de Marx quando este vivia; cf., por exemplo,
} Bakunin (2001). tual; foram suicidas ou homicidas Roland Barthes, Nicos Poulantzas e Louis Althusser; Georg Lukács abjurou inúmeras vezes perante Stálin e sua corte; Sartre fazia da promiscuidade sexual e intelectual um valor moral e político; last but not the least, não podemos esquecer os nazistas Carl Schmidt e Martin Heidegger, que, após a queda do III Reich, encerraram-se em silêncios obsequiosos mas sem jamais renegarem os passados nacional-socialistas. Esses dados biográficos costumam aparecer apenas a título de introdução biográfica quando tratamos de cada um dos autores em questão, mas um exame aprofundado das condições de sanidade dos teóricos sociais ainda está por ser feito - exame que, como se pode perceber, não é nem um pouco ocioso, tal a incidência de problemas ou distúrbios psicológicos ou emocionais. A despeito dos problemas de todos esses autores, os comentadores, exegetas e discípulos de variados estilos não costumam levar em consideração tais aspectos biográficos, pois assumem que não interferem na produção teórica ou até mesmo que, se interferirem, não têm importância negativa para a sua validade intelectual. Assim, apresenta-se com clareza a seguinte questão: por que a gritante duplicidade de critérios em que se considera que a "loucura" de Comte é prejudicial mas os sérios problemas emocionais e psicológicos de todos os demais autores não o é? Parece-nos que a resposta é simples: além de simples hipocrisia, trata-se do recurso sistemático ao já citado sofisma ad hominem como estratégica retórica para desqualificar o pensamento de Augusto Comte ${ }^{8}$

Mas, a despeito de sua irrelevância para a prática intelectual, é importante considerar a tese da loucura em si mesma, pelo que ela revela e devido às clivagens que surgem a partir dela na avaliação da obra de Comte; para isso, é necessário apresentarmos um pequeno resumo biográfico do pensador francês.

\footnotetext{
8 Talvez a observação acima cause espanto ou estranheza. Mas, parece-nos, isso é mais devido a uma sistemática ausência de uma Sociologia das Ciências Sociais que por qualquer outro motivo. De qualquer forma, tal empreendimento não seria difícil de realizar: do ponto de vista teórico-metodológico, uma combinação entre alguns estudos de Pierre Bourdieu (2004) e de Quentin Skinner (2002, especialmente cap. 2-6) permitiriam um excelente ponto de partida.
} 
Tendo nascido em 1798 em Montpellier, no Sul da França, Augusto Comte foi sozinho para Paris durante a adolescência para estudar na École Polytechnique. Devido a problemas políticos, foi expulso desse estabelecimento, voltou por um curto período para Montpellier e fixou residência, afinal, em Paris em 1816. Para manter-se, lecionava Matemática como professor particular e, durante alguns anos, foi secretário de Saint-Simon; ainda assim, sua vida era financeiramente austera e sua disciplina intelectual, bastante rigorosa. Eis que, em 1825, casou-se com Carolina Massin; essa moça, inteligente e um pouco mais jovem que o próprio Comte, era uma prostituta a quem o pensador, solitário em Paris, resolveu auxiliar via casamento (em caso contrário, ela seria presa devido às suas atividades profissionais), esperando uma retribuição na forma de companheirismo e, claro, fidelidade. É perfeitamente possível afirmar que tal ação foi um excesso romântico: mas, embora o procedimento de Comte tenha sido evidentemente ingênuo, em si não foi ruim, ou melhor, não representou demência, loucura ou desequilibro mental, mas simples inexperiência de vida, além de indicar generosidade pessoal. Carolina Massin, todavia, não correspondeu aos anseios de Comte, pois que sistematicamente o traía, retornando aos seus hábitos profissionais anteriores; da mesma forma, ela insistia em que Comte deveria usar seus talentos intelectuais para ganhar dinheiro, sem maiores preocupações com o projeto intelectual que ele desenvolvia. Essa situação tornou-se insustentável e, em meados de 1826, a combinação da penúria material com o descaso intelectual e as traições da esposa, além dos esforços intelectuais próprios - em 1826 Comte deu início à apresentação oral e pública do seu Curso de filosofia positiva -, resultaram em um sério esgotamento nervoso, que chegou ao ponto de uma tentativa de suicídio. Nos dois anos seguintes Comte recuperou-se paulatinamente desse episódio, retomou suas atividades e, em 1830, iniciou a publicação da Philosophie, projeto que só se completou em 1842, quando se separou de Carolina Massin (embora restrita à separação de corpos e mantendo uma pensão vitalícia).

Ao longo da década de 1840, Comte estava sozinho e com suas dificuldades financeiras, ao mesmo tempo que se preparando para avançar em suas elaborações intelectuais. Enquanto descansava e refletia para o que seria a sua Politique, conheceu a irmã de um de seus alunos em 1844:
Clotilde de Vaux. Essa moça, com cerca de 30 anos de idade, tinha uma situação marital semelhante à de Comte, pois que fora abandonada por um marido devedor e caloteiro - e, assim, fugitivo da polícia. Comte apaixonou-se por ela, mantendo um relacionamento platônico a partir de 1845; ela, de início assustada, paulatinamente passou a respeitar e até a corresponder ao afeto. Com tuberculose, em 1846 Clotilde de Vaux faleceu. Esse breve e intenso relacionamento marcou uma inflexão fundamental na obra de Comte, que a partir dali passou a enfatizar mais os sentimentos e menos a inteligência; ou melhor, subordinou a inteligência aos estímulos afetivos (altruístas ou egoístas). Não somente ocorreu um redirecionamento teórico como a própria produção de Comte intensificou-se: em 1848 ele redigiu dois livros, Discours sur l'esprit positive (COMTE, 1990) e o Discours sur l'ensemble du Positivisme (COMTE, 1957)9; depois, entre 1851 e 1854 redigiria os quatro volumes da Politique (COMTE, 1890); em 1853, o Cathéchisme positiviste (COMTE, 1934); em 1855, o Appel aux conservateurs (COMTE, 1899) e, em 1856 , o volume I e único dos quatro planejados da Synthèse subjective (2000b), além de sua extensa correspondência. Essa fase marca a afirmação do "método subjetivo" e da criação da Religião da Humanidade.

A passagem do Positivismo "filosófico" para o "religioso" produziu dissensões ou "deserções", como a indicada por Giddens a respeito de Stuart Mill (apud GIDDENS, 2001, p. 223): "decadência melancólica de um grande intelecto". Comte morreu prematuramente em 1857, deixando seus bens (aí incluídos os direitos autorais de suas obras) para um grupo de 13 executorestestamenteiros. Logo em seguida, a viúva, Carolina Massin, procurou leiloar todos os bens de Comte e anular o testamento, o que iniciou um processo judicial que se estendeu até 1870 . Esse processo visava a permitir que Massin editasse as obras de Comte, retirando as várias referências elogiosas a Clotilde de Vaux e as referências negativas a ela própria; além disso, em associação com o ex-discípulo de Comte, o dicionarista Littré, pretendia permitir a publicação apenas do que fora escrito durante a convivência conjugal (essencialmente a Philosophie), classificando, não por

9 O Discours sur l'ensemble seria incorporado ao volume I da Politique, a título de "Prefácio geral", em 1851. 
acaso, de "produto de loucura" tudo aquilo que foi escrito depois da separação conjugal. O resultado desse longo litígio foi que, com base em laudos médicos, em testemunhos e na análise do testamento, a Justiça da França deu ganho de causa aos executores-testamenteiros, recusando assim a tese da loucura (cf. LACERDA NETO, 2004, p. 211-219).

Retomando a discussão anterior: o que Giddens (2001) faz, ao retomar o tema da loucura de Comte, é adotar um discurso que visa a desqualificar de maneira rápida e superficial a obra religiosa de Comte, pois que não a examina em momento algum, e reduzindo o corpus comtiano à Philosophie - e, ainda por cima, a partir de um relato sórdido ${ }^{10}$

\section{II.3. Filosofia das Ciências}

Vimos acima que várias das opiniões atribuídas por Giddens a Comte não procedem; essas opiniões supostamente se refeririam à obra valorizada com a acusação de loucura, ou seja, referem-se à Philosophie. Em que consistiu essa volumosa obra escrita em 12 anos e seis volumes? Em um exame sistemático das ciências abstratas constituídas até então, de acordo com a "escala enciclopédica" de Comte; a seqüência seria a seguinte: Matemática, Astronomia, Física, Química e Biologia. Esse exame das ciências não era um fim em si mesmo, mas um meio para um fim ambicioso: a constituição da ciência da sociedade, inicialmente chamada de "Física Social" e depois renomeada para "Sociologia". Os três primeiros volumes foram dedicados a essa progressão de ciências preliminares; já os três últimos trataram da definição do objeto e do método da nova ciência, incluindo aí as tentativas anteriores e as principais questões teóricas (especificamente, a Estática e a Dinâmica sociais).

Convém notarmos que, a propósito da mudança de nome da Sociologia, Giddens afirma que foi devida ao projeto de estatística social de Quetélet,

10 Pode parecer estranho o uso de expressões como "sórdido" em um artigo científico de Teoria Social; entretanto, não apenas não é possível qualificar de outra forma o episódio como, por outro lado, o próprio Comte afirmava que não se pode conhecer a realidade social sem a referência a valores (COMTE, 1890, v. II, cap. 1, 4); por fim, a compreensão das várias fases da carreira comtiana não é possível sem a adoção de juízos de valor (como mesmo Giddens implicitamente admite). vista por Comte "com desdém" (GIDDENS, 2001, p. 222). A referência à proposta de matematização da sociedade é correta, mas o "desdém" afirmado por Giddens sugere algo como ciúme profissional, ou seja, uma motivação mesquinha, além de intelectual e teoricamente pobre. Essa insinuação é incorreta: ao insistir em seu projeto específico de ciência da sociedade, a preocupação de Comte era preservar a especificidade teórico-metodológica da Sociologia, indicando que ela é irredutível às demais ciências tanto em termos de objeto quanto de método - o que, no caso da proposta de Quételet, a intenção era evitar que a ciência social fosse reduzida, desde o início, à sociometria. Mais ainda: em vez de a Sociologia (e, por extensão, as Ciências Humanas) dever subordinar-se às Ciências Naturais, seriam estas que deveriam subordinar-se teoricamente à Sociologia, a partir de uma perspectiva que hoje chamaríamos de transdisciplinar, radicalmente humanista (esse é o sentido da "síntese subjetiva" de Comte).

A Politique assume que a Sociologia já foi criada e, a partir disso, consiste em um aprofundamento sistemático dessa perspectiva humanista (COMTE, 1890, v. I, Préface; v. III, Préface), por assim dizer "subjetivista" e "qualitativista", das teorias sociológicas. Tal aprofundamento considera, por um lado, as instituições comuns a todas as sociedades humanas (religião, família, linguagem, propriedade, governo) - é a Estática Social, apresentada no volume II - e as mudanças por que essas instituições passaram ao longo da história e suas inúmeras interações ("reflexivas", para usar o jargão de Giddens) - é a Dinâmica Social, do volume III da Politique. O volume I da Politique apresenta, em suma, considerações epistemológicas diversas; já o volume IV apresenta um quadro geral do que seria a sociedade ideal, em que o ser humano pode realizar-se ao máximo de acordo com as suas potencialidades reveladas historicamente: é, literalmente, a utopia positivista. Nesses livros Comte discute concepções de justiça social, de liberdades públicas e assim por diante (cf., por exemplo, LACERDA, 2004; 2008a; 2008b; 2009a).

Essa digressão foi necessária para indicar qual o sentido dos relatos de Giddens: é afirmar um Augusto Comte "cientificista", "naturalista", mesmo "quantitativista". Veremos em detalhes na próxima seção que, para Giddens, qualquer "Positivismo" tem necessariamente tais características; aqui ainda importa contrapor algumas das 
perspectivas sociológicas que Giddens atribui a Comte com o que o próprio Comte dizia. Assim, a respeito de Filosofia da Ciência: "O Curso [a Philosophie] apresenta uma extensa análise do desenvolvimento das ciências como preâmbulo necessário ao seu programa prático por meio da tese de que a evolução progressiva, porém ordeira, da ciência fornece o modelo para uma evolução paralela da sociedade como um todo. O que diria Comte à moderna filosofia da ciência que, nos trabalhos de Bachelard, Kuhn e outros, suplantou a evolução com a revolução bem no âmago da própria ciência natural?" (GIDDENS, 2001, p. 224-225; grifo no original). Esse trecho apresenta duas questões: por um lado, atribui a Comte um relato da evolução das ciências segundo o qual ela teria sido "ordeira" e que, além disso, serviria como modelo para o desenvolvimento social; por outro lado, contrapõe uma perspectiva "evolucionista" (Comte) a uma outra "revolucionária" (Bachelard, Kuhn) do desenvolvimento científico. Vejamos cada uma delas em separado.

Para Comte, o desenvolvimento das ciências não é "ordeiro", isto é, isento de conflitos ou sobressaltos. Deixando de lado o fato de que atribuir a Comte um desenvolvimento "ordeiro" é uma forma de torná-lo um apologeta da "ordem", isto é, um conservador ou mesmo um reacionário (cf. GIDDENS, 2001, p. 222) ${ }^{11}$, a narrativa comtiana do desenvolvimento das ciências é muito clara e muito rica ao tratar dos conflitos teóricos entre autores, escolas e "epistemes". Antes de mais nada, a lei dos três estados indica que as concepções humanas passam por três fases (teológica, metafísica e positiva) e que há, precisamente,

11 No seguinte trecho, temos a clara impressão de que, segundo Giddens, Comte era um teórico exclusivamente da “ordem”, um conservador, talvez um reacionário: “[...] o tipo de sociedade previsto por Comte com a garantia de ambos, ordem e progresso, dava grande importância às características constantes dos trabalhos da 'escola retrógrada' [...], ainda que destituídas de associação específica com o catolicismo" (GIDDENS, 2001, p. 222); aqui e ali Giddens usa a expressão "progresso com ordem" no mesmo sentido. Essas observações são chocantes à luz da defesa doutrinária que Comte fez dos direitos trabalhistas (incluindo o direito de greve), a radical liberdade de pensamento e de expressão, do fim dos impérios coloniais (a começar pelo da França, em relação à Argélia), da defesa da justiça social e do combate ao liberalismo laissez-faire e "burguesocrata", do apoio aos proletários parisienses que se sublevaram no início de 1848 e diversas outras medidas. conflitos entre as várias tradições: esses conflitos são solucionados de acordo com as condições sociais gerais e também com o confronto com a realidade cósmica. A relação causal geral, portanto, não é da ciência para a sociedade, mas, ao contrário, da sociedade para a ciência: ou seja, os conhecimentos humanos desenvolvem-se conforme as condições e as necessidades sociais. Os conflitos sociais não deixam de ser refletidos nos conflitos teóricos; além disso, o surgimento das ciências, embora tenha obedecido a uma seqüência histórica e lógica muito clara, nem por isso foi "contínuo": basta ver que a Matemática e a Astronomia surgiram na Antigüidade (egípcia e grega) e só foram decididamente retomadas após o Renascimento, havendo um enorme lapso que compreende o Império Romano e a Idade Média entre ambos os extremos. O comentário ligeiro de Giddens apresenta ainda dois problemas teóricos: em primeiro lugar, ele mistura a constituição de corpos teóricos abstratos a respeito de fenômenos específicos com o desenvolvimento da sociedade, ou, o que dá no mesmo, mistura o abstrato com o concreto; em segundo lugar, ele pretende invalidar uma observação teórica (abstrata) apenas porque a realidade prática (concreta) é múltipla e variada - o que equivale a negar a (possibilidade de) teoria com a platitude de que a "realidade é inesgotável".

A respeito da concepção de ciência de Comte face à concepção "moderna". Deixando de lado os fatos de que Giddens propõe um evolucionismo canhestro (em que o que vem depois é sempre melhor do que o que veio antes) e de que as concepções "modernas" têm sempre um quê de simples modismo, tanto a concepção comtiana não é "evolucionista" quanto o caráter "revolucionário" atribuído às mudanças paradigmáticas é discutível. Vimos acima que para Comte há uma estreita relação entre as condições sociais gerais e o desenvolvimento do conhecimento em cada sociedade; mas, além disso, as passagens das concepções teológicas para as metafísicas e destas para as positivas são sempre "revolucionárias", pois que envolvem amplas visões de mundo. Basta pensar na passagem do modelo geocêntrico para o heliocêntrico: para Comte, o deslocamento do centro do universo teve conseqüências radicais, tendo sido o responsável direto pela decadência intelectual da teologia. Mas, de maneira mais decisiva, a passagem das fases teológica e metafísica para a positiva é muito mais importante; ela con- 
siste em passar do absolutismo filosófico para o relativismo, nisso consistindo a "revolução moderna", para Comte.

Mas a idéia de "revolução" na filosofia da ciência moderna não é unívoca. Antes de mais nada, convém elucidar o sentido das palavras "revolução" e "evolução". A "revolução" pode ser uma mudança brusca (às vezes violenta) e/ou uma mudança radical; a "evolução" pode ser uma mudança gradual e/ou uma mudança pacífica. Como Giddens adota a expressão "evolução" como equivalente epistemológico para "ordem" ou "conservadorismo", o que se depreende é que, para Comte, as mudanças teóricas são incrementalistas e "controladas". É difícil conceber uma afirmação mais gratuita que essa, que aprisiona em uma camisa de força a compreensão da prática científica e teórica. Tanto Comte quanto Bachelard e Kuhn afirmam que as mudanças científicas ocorrem de maneira incremental $e$ de maneira abrupta; além disso, é há muito sabido que não é possível "controlar" as descobertas científicas, tanto no sentido socialmente disruptivo quanto no sentido da própria prática científica. Em outras palavras, Giddens adota duas categorias desnecessariamente restritivas e excludentes para poder forçar Comte em uma delas, que são também as menos valorizadas.

\section{DIFERENCIANDO OS "POSITIVISMOS"}

A concepção de um Comte "cientificista" de Giddens torna-se mais clara no longo artigo intitulado "Comte, Popper e o Positivismo" (GIDDENS, 1998). O objetivo desse texto é esclarecer o sentido da expressão genérica "Positivismo", indicando a descendência intelectual que vai de Comte a Mach, ao Círculo de Viena e a Popper, em termos de Filosofia das Ciências, e de Comte a Durkheim e ao funcionalismo, na Teoria Social. Esse artigo de Giddens, portanto, insere-nos em uma discussão mais ampla, que já foi tratada por outros autores, embora não necessariamente a respeito da Teoria Social. Podemos citar apresentações gerais do que é o "Positivismo", além da de Giddens, as de Kolakowski (1976) e de Arana (2007), que são sucintas e bastante informativas. Todas elas, no entanto, apresentam um grave defeito: no esforço de buscar um denominador comum para a expressão "Positivismo", deixam de lado importantes aspectos particulares de cada teoria ou escola e realçam outros aspectos que não possuem in- trinsecamente a importância atribuída pelos organizadores. Dessa forma, esse esforço de afirmar a validade do uso do rótulo "Positivismo" consiste em forçar a entrada de movimentos teóricos diversos em uma categoria única; importa nisso muito menos as idéias de cada uma das teorias reunidas do que o valor operatório do rótulo.

Ao definirmos a expressão "Positivismo", é possível estabelecermos uma comparação com o "marxismo": assim como há uma grande polissemia a respeito do marxismo, sendo necessário explicitar a qual marxismo faz-se referência, há também uma grande polissemia com o Positivismo. Entretanto, ao contrário do marxismo, em que é possível - na verdade, é necessário - fazer de alguma forma referência a Marx, no caso do Positivismo as referências necessárias a determinados autores não são possíveis, ocorrendo na prática ou a utilização de um rótulo ou a subsunção de perspectivas metodológicas (em alguns poucos casos, teóricas) sob uma rubrica comum. Embora nesses casos a referência a Augusto Comte seja corrente, ela não costuma ser fácil, simples ou, como veremos, justificada.

Em um esforço para elucidar esses diferentes sentidos, Peter Halfpenny escreveu um opúsculo chamado Positivism and Sociology (HALFPENNY, 1982), em que identificou 12 sentidos para a palavra "Positivismo". Vejamos quais são eles.

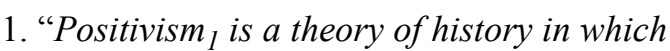
improvements in knowledge are both the motor of progress and the source of social stability (Comte 1$)$.

2. Positivism 2 is a theory of knowledge according to which the only kind of sound knowledge available to humankind is that of science grounded in observation (Comte 2 ).

3. Positivism 3 is a unity of science thesis according to which all sciences can be integrated into a single natural system (Comte 3 ).

4. Positivism 4 is a secular religion of humanity devoted to the worship of society (Comte ${ }_{4}$ ).

5. Positivism ${ }_{5}$ is a theory of history in which the motor of progress that guarantees the emergence of superior forms of society is competition between increasingly differentiated individuals (Spencer). 
6. Positivism 6 is a theory of knowledge according to which the natural science of sociology consists of the collection and statistical analysis of quantitative data about society (Durkheim).

7. Positivism 7 is a theory of meaning, combining phenomenalism and logicistic method, and captured by the principle of verifiability, according to which the meaning of a proposition consists in its method of verification (logical positivism ${ }_{1}$ ).

8. Positivism $_{8}$ is a programme for the unification of sciences both syntactically and semantically (logical positivism ${ }_{2}$ ).

9. Positivism 9 is a theory of knowledge according to which science consists of a corpus of interrelated, true, simple, precise and wide-ranging universal laws that are central to explanation and prediction in the manner described in the D-N [deductivenomological] schema (Hempel).

10. Positivism 10 is a theory of knowledge according to which science consists of a corpus of causal laws on the basis of which phenomena are explained and predicted.

11. Positivism 11 is a theory of scientific method according to which science progresses by inducting laws from observational and experimental evidence (Bacon).

12. Positivism 12 is a theory of scientific method according to which science progresses by conjecturing hypotheses and attempting to refute them, so that false conjectures are eliminated and corroborated ones retained (Popper)" (idem, p. 114-115; sem grifos no original $)^{12}$.

12 No original, essa relação consiste de apenas um único e longo parágrafo, que dividimos para facilitar a compreensão. Tradução livre: "O Positivismo 1 é uma teoria da história em que os desenvolvimentos do conhecimento são tanto o motor da história quanto a fonte da estabilidade social (Comte 1). O Positivismo 2 é uma teoria do conhecimento de acordo com a qual o único tipo são de conhecimento disponível para a humanidade é o da ciência baseada na observação (Comte 2). O Positivismo 3 é uma tese da unidade da ciência segunda a qual todas as ciências podem ser integradas em um único sistema natural (Comte 3). O Positivismo 4 é uma religião secular da Humanidade devotada à veneração da sociedade (Comte 4). O Positivismo 5 é uma teoria da história em que o motor do progresso que
A relação acima é bastante esclarecedora; embora apresente alguns problemas sérios ${ }^{13}$, Halfpenny esclarece que há inúmeras formas de "Positivismo" que não se referem (diretamente) a Augusto Comte - no caso, oito em 12, isto é, dois terços. Além dos sentidos 1 a 4 , poderíamos também incluir na rubrica comtiana o nono, relativo às leis naturais.

Parece claro que a relação acima está longe de esgotar o assunto; além dos sentidos habituais relativos à Sociologia e à Filosofia das Ciências, podemos incluir alguns outros. Nesse sentido, é ne-

garante o surgimento de formas superiores de sociedade é a competição entre indivíduos crescentemente diferenciados (Spencer). O Positivismo 6 é uma teoria do conhecimento de acordo com a qual a ciência natural da Sociologia consiste na coleção e na análise estatística de dados quantitativos sobre a sociedade (Durkheim). O Positivismo 7 é uma teoria do significado, combinando métodos fenomenológicos e lógicos e obtida pelo princípio da verificabilidade, de acordo com o qual o significado de uma proposição consiste em seu método de verificação (Positivismo Lógico 1). O Positivismo 8 é um programa para a unificação das ciências, tanto sintática quanto semanticamente (Positivismo Lógico 2). O Positivismo 9 é uma teoria do conhecimento de acordo com a qual a ciência consiste em um corpus de leis universais interrelacionadas, verdadeiras, simples, precisas e de amplo alcance que são centrais para a explicação e para a previsão, à maneira descrita pelo esquema DN [dedutivo-nomológico] (Hempel). O Positivismo 10 é uma teoria do conhecimento de acordo com a qual a ciência consiste em um corpus de leis causais, a partir dos quais os fenômenos são explicados e previstos. O Positivismo 11 é uma teoria do método científico de acordo com a qual a ciência progride por meio de leis indutivas a partir de provas observacionais e experimentais (Bacon). O Positivismo 12 é uma teoria do método científico de acordo com a qual a ciência progride conjecturando hipóteses e tentando refutálas, de modo que as conjecturas falsas são eliminadas e as corroboradas são retidas (Popper)".

13 Por exemplo: afirmar que a Sociologia de Durkheim é particularmente quantitativa, o que é verdade em particular para $O$ suicídio, mas deixando de lado todas as demais grandes obras (A divisão do trabalho social, As formas elementares da vida religiosa e mesmo As regras do método sociológico). No que se refere a Comte, podemos indicar o seguinte: na definição 1 , o que garante a estabilidade social não é o conhecimento (de uma perspectiva estritamente intelectual), mas os sentimentos (em particular, os altruístas); na definição 3, a escala enciclopédica é concluída pela Sociologia e pela Moral e são elas que devem orientar esse conjunto; na definição 4, o objeto de culto da Religião da Humanidade não é a "sociedade", mas uma abstração relativa ao conjunto dos seres humanos altruístas, historicamente constituída. 
cessário distinguirmos duas variedades "disciplinares" de Positivismo que guardam poucas relações com o que nos interessa aqui; são elas o Positivismo Jurídico e o Histórico. O primeiro, também chamado de "Juspositivismo", é obra do austríaco Hans Kelsen, que no início do século $\mathrm{XX}$ afirmou, grosso modo, que as fontes do Direito têm que ser buscadas apenas no próprio Direito ${ }^{14}$, excluindo-se as fontes extrajurídicas, como hábitos e costumes compartilhados, além de valores disseminados socialmente. Sem nos determos em uma extensa crítica a seu respeito, importa notar que essa perspectiva, se abre a possibilidade de uma Sociologia do Direito a partir da consideração do Direito como um sistema fechado em si mesmo, em seus próprios termos nega a possibilidade de considerar na prática o Direito como integrante de um sistema maior (o sistema social), que o informe com outros princípios juridicamente aplicáveis. Como veremos adiante com maiores detalhes, esse raciocínio não integra o pensamento comtiano, pois que este estava preocupado fundamentalmente em constituir um sistema de valores socialmente compartilhado capaz de regular as relações sociais e dirimir os conflitos sociais; secundariamente, convém notar que Augusto Comte simplesmente não tratou do Direito e as suas referências aos juristas eram, de modo geral, negativas, devido ao caráter metafísico deles, que negava precisamente as considerações sociológicas ${ }^{15}$.

O Positivismo na História seria aquela corrente iniciada com a obra do historiador alemão Leopold von Ranke, que no século XIX definiu que "os documentos falam por si próprios", consistindo o trabalho do historiador em apresentar os "fatos" indicados pelos documentos. Assim,

14 Como o Direito escrito é o chamado "Direito Positivo", a afirmação de que ele é a única fonte do Direito é o "positivismo jurídico".

15 A confusão entre os positivismos, no presente caso, surge também por um outro motivo: o juspositivismo batese contra as várias escolas de Direito Natural, que são percebidas como ilegítimas e, segundo a terminologia comtiana, como metafísicas, isto é, inválidas. Entretanto, Comte não nega o Direito Natural para reduzir o Direito ao que está escrito: ele informaria pesadamente o Direito com a sua Sociologia e também, nos dias atuais, com a Antropologia. Para uma exposição pormenorizada do Positivismo Jurídico, cf. Bobbio (2001). além de carecer de interpretações e de hipóteses de fundo, essa historiografia caracterizar-se-ia por ser dedicada aos fenômenos políticos, isto é, aos atos dos "grandes líderes" e à vida (política) das nações, sem dúvida aí incluídas as guerras. $\mathrm{O}$ Positivismo comtiano afasta-se dessa modalidade em primeiro lugar porque a historiografia por ele sugerida não consiste, metodologicamente, na acumulação de fatos ou na ausência de hipóteses interpretativas; em segundo lugar, porque em termos teóricos a historiografia proposta por Augusto Comte é de caráter sociológico, vinculada a "grandes durações": de fato, desde o início da carreira Comte afirmou que é necessário o pensamento social ultrapassar a crônica mais ou menos anedótica da vida política e passar para uma perspectiva totalizante da vida social (em que o político não ocupa o nível fundamental) e em que os acontecimentos sociais engendram a si mesmos, continuamente, no método por ele denominado, com precisão, de "filiação histórica" (cf. COMTE, 1890 , v. III; 1895; 1972). Nesse sentido, não é difícil de perceber nem de sugerir uma continuidade teórico-metodológica entre Comte e a Escola dos Anais ${ }^{16}$.

Enquanto as duas variedades de Positivismo acima indicadas são disciplinares, uma outra vertente é por assim dizer substantiva, isto é, constitui uma corrente filosófica, correspondendo aos sentidos 7 e 8 de Halfpenny: é o "Positivismo Lógico", também conhecido por "Neopositivismo", "Empirismo Lógico" e "Círculo de Viena". Demarcar a diferença dessa corrente com o Positivismo comtiano exige maiores comentários.

Antes de mais nada, enquanto a expressão "Círculo de Viena" indica a origem dos pensadores agrupados em torno de um determinado projeto intelectual, "Empirismo Lógico" designa com grande precisão o conteúdo desse projeto intelectual; já "Neopositivismo" é uma expressão menos descritiva e que apresenta o demérito de ser profundamente elusiva para o nosso presente fim. Na verdade, mesmo os "neopositivistas" desgostavam dessa expressão, tanto por ser pouco descritiva de suas preocupações intelectuais, como porque as remetia às idéias de Comte - com quem, aliás, não

16 Para uma distinção mais pormenorizada sobre o Positivismo em História, cf. Reis (2004). 
mantinham grandes afinidades (cf. HALLER, 1990, p. 47) ${ }^{17}$. Além disso, o nome "Empirismo Lógico" esclarece as marcadas distâncias entre Comte e o Círculo de Viena, pelo apego deste grupo às questões puramente empíricas somadas à análise lógica das expressões lingüísticas utilizadas no dia-a-dia e na ciência. Mais do que isso: o "Empirismo Lógico" esclarece a origem do senso comum acadêmico que atribui ao "Positivismo" a pesquisa dos "fatos puros": embora descrever dessa forma o projeto do Círculo de Viena seja redutor (e, até certo ponto, injusto), chegando ao ponto de constituir o sofisma do espantalho ${ }^{18}$, o fato é que a exigência de rigorosamente corresponder a toda afirmação um fato empírico é do Círculo de Viena, não de Comte (cf. DUTRA, 2005, seção 2.2).

Há pontos de contato entre a obra de Comte e as idéias do Círculo de Viena, o que atrapalha um pouco a diferenciação: por exemplo, os sentidos 3 e 8 , ou 2 e 9-12, da relação de Halpenny ${ }^{19}$. Isso permite que alguns autores - continuemos, para os presentes fins, com Giddens (cf. GIDDENS, 1998, p. 178) - a forçar os argumentos no sentido de apresentar Comte como neopositivista avant la lettre 20 .

17 A página indicada acima cita uma carta escrita por Otto Neurath - um dos fundadores do Círculo de Viena, tanto em sua versão de 1909 quanto em segunda versão, vinte anos posterior - para Rudolph Carnap em que manifesta seu profundo desagrado com a obra de Comte - e, daí, seu repúdio ao adjetivo "positivista".

18 O sofisma do espantalho consiste em simplificar ao extremo uma perspectiva filosófica ou um argumento nesse movimento descaracterizando-o - para "refutá-lo".

19 Vejamos novamente: 2) teoria do conhecimento, em que o único tipo são de conhecimento é a ciência baseada na observação; 3) tese da unidade da ciência, em que todas as ciências podem ser integradas em um único sistema natural; 8) programa para a unificação das ciências, tanto sintática quanto semanticamente; 9) teoria do conhecimento de acordo em que a ciência consiste em um corpus de leis universais interrelacionadas, segundo o modelo dedutivonomológico; 10) teoria do conhecimento, em que a ciência consiste em um corpus de leis causais; 11) teoria do método científico, em que a ciência progride por meio de leis indutivas, com provas observacionais e experimentais; 12 ) teoria do método científico, em que a ciência progride conjecturando hipóteses e tentando refutá-las.

20 O seguinte comentário de Giddens é esclarecedor, nesse sentido: "Considerarei a influência de Comte apenas sob dois aspectos. As formas pelas quais seus escritos por Durkheim e a extensão em que as concepções de Comte
Nesse sentido, a definição de "Positivista" costuma ser reduzida a algumas características: 1) a rejeição da teologia e da metafísica e 2) a afirmação da empiria (o que, em alguns casos ou em algumas versões, é tomada como a referência aos "fatos puros"); 3) como conseqüência das características anteriores, a afirmação da ciência como conhecimento verdadeiro da realidade. Essa definição tripla, bastante comum e popular, na verdade é superficial e redutora; um exame preliminar indica que, com um mínimo de rigor teórico e metodológico, pode-se englobar nela não apenas os assim chamados "positivistas" como todas aquelas linhas teóricas e metodológicas que valorizam a ciência, não se incomodam com a teologia, rejeitam puras entidades abstratas e exigem a referência a "fatos" empíricos: em certo sentido, virtualmente todas as teorias sociológicas.

Examinemos as características indicadas acima, começando pela rejeição da teologia e da metafísica. A postura de Comte era de ultrapassar ambas essas formas de interpretar a realidade em favor da científica - ou, sendo mais específico, em favor da interpretação "positiva" da realidade. Enquanto a teologia e a metafísica são absolutas, pesquisando questões inacessíveis ao ser humano (de onde viemos? Para onde vamos? Qual a "essência" da vida e da realidade?), a positividade é relativa, isto é, percebe que tudo é relativo para e ao ser humano e, portanto, pesquisa apenas as relações entre seres e fenômenos: a partir daí, substitui a pesquisa das causas primeiras e finais pelas relações percebidas abstratamente entre fenômenos, ou seja, pelas leis. Mas ao advogar o conhecimento positivo da realidade, ao afirmar que a teologia e a metafísica são perspectivas irreais (no sentido de que não permitem um conhecimento da realidade), Comte não deixa de lado a perspectiva sociológica, isto é, histórica: para ele, teologia e metafísica foram condições necessárias e, em seu momento, insubstituíveis no desenvolvimento do espírito humano; nesse sentido, devem ser respeitadas. Por outro lado, o conhecimento da realidade pode ser analítico ou sintético: primeiro analítico, referente a aspectos isolados da realidade, por meio da ciência; em seguida sintéti-

obedeceram intelectualmente ao programa filosófico desenvolvido pelo positivismo lógico" (GIDDENS, 1998, p. 178; sem grifos no original). Uma autora que segue essas propostas de Giddens é Alcântara (2008). 
co, elaborando uma visão de conjunto dessa mesma realidade mas atendendo também a necessidades psicológicas não apenas intelectuais, mas afetivas e por assim dizer psíquicas: essa visão de conjunto, essa síntese, é obra da filosofia ${ }^{21}$. Dessa forma, em Comte há claras, embora pouco conhecidas, distinções entre, de um lado, ciência e positividade e, por outro lado, ciência e filosofia: a positividade é maior que a ciência, embora baseie-se nela; a filosofia não se reduz à ciência e, embora baseie-se nela, tem seu âmbito de pesquisas irredutível ao da ciência.

De maneira semelhante, o Círculo de Viena tinha em alta conta a ciência e em péssima conta a teologia e a metafísica ${ }^{22}$. Teologia e metafísica, não se referindo a questões de fato - empíricas, isto é, sujeitas a comprovação sensorial - eram percebidas como afirmações sem sentido. Por outro lado, sendo a ciência o estudo da realidade, as afirmações científicas tinham que ter uma estrutura lógica a que se faria correspondência com a realidade ${ }^{23}$. Considerando as obras de pensado-

21 A partir de uma perspectiva kantiana, os conceitos de "analítico" e "sintético" esposados pelo Círculo de Viena diferiam marcadamente dos de Comte: Comte considera que o sintético é aquilo que apresenta uma visão de conjunto, ou seja, são as observações concretas e também a elaboração filosófica de conjunto; o analítico corresponde às perspectivas que estudam questões específicas dos fenômenos (cf. COMTE, 1934); a perspectiva kantiana, por outro lado, considera que uma afirmação analítica é puramente intelectual (as verdades matemáticas, por exemplo), ao passo que as afirmações sintéticas são aquelas originárias das observações concretas, ou seja, todas as que não são puramente originárias da inteligência (cf. SALMON, 1969, p. 131-135).

22 Convém notarmos que o uso da expressão "Círculo de Viena" é um tanto arriscado: afinal, as perspectivas esposadas por seus membros não eram necessariamente concordantes entre si (chegando mesmo, em alguns casos, a serem contraditórias) - embora, por questões de propaganda intelectual e, daí, de um certo corporativismo, afirmassem alguns que havia uma unidade de pensamento entre eles (cf. AYER, 1959; HALLER, 1990, cap. 2; DUTRA, 2005, seções 2.2-2.3).

23 Dessa preocupação, é importante notarmos, desenvolveu-se um dos mais profícuos e importantes programas de pesquisas filosóficas e epistemológicas do século XX, investigando-se as condições de correspondência entre enunciados e fatos, a estrutura de obtenção e de checagem dos fatos, a comprovação ou refutação de teorias científicas e assim por diante. res como Platão, Espinoza, Hegel etc., a filosofia era percebida como sinônima de metafísica; para ter algum sentido intrínseco, ela deveria mudar de objeto e de procedimento e referir-se à análise das afirmações científicas, o que resultou em análise lingüística e lógica das afirmações - ou, de maneira mais precisa: a filosofia foi reduzida à análise lógica e lingüistica das proposições cientificas.

Não é difícil perceber as diferenças entre Comte e o Círculo de Viena no que se refere à teologia e à metafísica - e, por extensão, também à filosofia. Não se trata de afirmar que há em Comte uma "reabilitação" delas; o que ocorre é que o pensador francês reconhecia seu inevitável papel histórico para o ser humano, de modo que a simples e direta afirmação de que elas são sem sentido não cabe no sistema comtiano; muitas das obras e das idéias teológicas e metafísicas conservariam seu valor no caso de serem "traduzidas" para o espírito positivo ${ }^{24}$. Afirma-se que à negação da teologia e da metafísica corresponde a "morte da filosofia": se deixarmos de lado a estreita definição de "filosofia" como sendo "metafísica" (ou também "teologia"), perceberemos que tanto no caso de Comte como no do Círculo de Viena isso é incorreto, embora possamos perfeitamente conceder que o papel da filosofia é bastante reduzido e empobrecido para o Círculo de Viena - mas não para Comte, que lhe concede uma grande digni$\operatorname{dade}^{25}$.

No que se refere à afirmação da empiria, há que se diferenciar as perspectivas de cada qual,

24 Dois exemplos marcantes disso: em primeiro lugar, Comte recomendava a leitura da obra do místico medieval alemão Tomás de Kempis, A imitação de Cristo, substituindo as referências teológicas ("deus", "Cristo" etc.) por expressões positivas, isto é, humanas e humanistas. Um esforço nesse sentido foi realizado pelo psiquiatra paulista Paulo de Tarso Monte Serrat (1983). Em segundo lugar, Comte afirmava que a "plena racionalidade positiva" exige a incorporação da primeira etapa da teologia - o fetichismo - no Positivismo (COMTE, 1890, v. III passim). Essa incorporação equivale ao reconhecimento de méritos lógi$\cos$, práticos e afetivos do fetichismo - o que chegou a receber o elogio expresso de Lévi-Strauss (2008, cap. VIII).

25 Contraste-se a discussão acima com a seguinte afirmação de Giddens (1998, p. 183): "Quando Comte e Mach falaram da preservação da filosofia, tratava-se da 'filosofia positiva': aqui filosofia era o esclarecimento lógico da base da ciência". 
novamente. Vimos há pouco que, para o Círculo de Viena, a correspondência das afirmações lingüísticas com fatos empíricos era uma exigência; todavia, essa exigência revelou-se com o passar do tempo, com o avançar das discussões internas ao grupo, mais como um postulado a ser investigado que como uma profissão de fé. No caso de Comte, a necessidade da empiria consiste muito mais na exigência da verificação das afirmações teóricas que na postulação de "fatos puros" e na descoberta da dinâmica da realidade pela simples inspeção dessa realidade e/ou pelo acumular de informações isoladas. Nesse sentido, Comte era bastante explícito: sendo a ciência o conjunto de leis abstratas, o acúmulo de informações esparsas é qualquer coisa menos útil; mas, de maneira mais decisiva, o conhecimento da realidade consistindo nas representações teóricas verificadas na realidade, só é possível saber o que procurar na realidade a partir de uma teoria prévia ${ }^{26}$, de tal sorte que o ser humano, para conhecer a realidade, constantemente "oscila" entre a postulação teórica e a observação empírica. Afirmando que a diferença metodológica entre a teologia e a metafísica, de um lado, e a ciência, de outro lado, é a subordinação (e não supressão) da imaginação à observação pela ciência, Comte considerava que a razão normal é sempre próxima ao bom senso comum e eqüidistante de dois vícios intelectuais opostos: o misticismo e o empirismo. O misticismo é a tendência a considerar que as teorias bastam por si sós e que os fatos empíricos são desnecessários; já o empirismo - que, para evitar ambigüidades, poderíamos chamar por meio do anglicismo "empiricismo" - consiste em considerar que a mera coleção de fatos é suficiente para conhecer a realidade 27 .

Um outro elemento que, segundos alguns, aproxima Comte e o Círculo de Viena é a idéia de uma ciência unificada. Mais uma vez, a referência ideal para essa aproximação é Giddens (1998,

26 Essa necessidade, aliás, é o que justifica o fato de a teologia e a metafísica serem o início necessário da marcha do espírito humano, pois que fornecem uma teoria atrativa o suficiente para manter a atenção humana concentrada em questões específicas por longos períodos de tempo - ainda que essas teorias revelem-se falsas e seus objetivos, inatingíveis.

27 Bem notadas as coisas, o jogo entre teoria e empiria é uma das maiores conquistas do movimento epistemológico chamado, ironicamente, de "pós-positivismo". p. 181-182); mas, novamente, tal aproximação é superficial e baseada em uma apreciação ligeira e desinformada dos projetos teóricos específicos. A proposta do Círculo de Viena era efetivamente unificar as ciências por meio de um linguajar por assim dizer neutro (isto é, axiologicamente neutro), capaz de expressar pelos mesmos símbolos e pelas mesmas operações lógicas os mais diferentes fenômenos. (Não é difícil de entender, com isso, a justiça do nome "Empirismo Lógico" autoatribuído ao grupo por alguns de seus membros.) Para Comte, a única possibilidade de "unificação" da ciência é por meio de um método geral adotado pelas diversas ciências particulares - a já referida subordinação da imaginação à observação - e por meio de teorias homogêneas, isto é, que possam comunicar-se entre si, relevando as relações dos vários fenômenos (das diversas ciências) entre si: qualquer coisa além disso é, segundo as palavras de Comte, "abusiva" (COMTE, 1890, v. I passim; v. II passim). Aliás, as intromissões indevidas de teorias de uma ciência em outra recupera um termo usado anteriormente: cada ciência tem sua dignidade própria, devendo preservar-se tanto do misticismo (explicar um fenômeno mais grosseiro por um mais nobre) quanto do materialismo (explicar um fenômeno mais nobre por um mais grosseiro $)^{28}$. A síntese filosófica, por outro lado, consiste na coordenação dos principais resultados de cada ciência necessários para que o ser humano possua uma visão de mundo (cosmológica e humana) coerente, capaz de conferir harmonia mental a cada um e também de permitir que cada um aja em sociedade: em outras palavras, consiste em um humanismo forte.

Retornemos a Giddens. Para argumentar que há uma relação entre Comte e o Círculo de Viena, Giddens apresenta Ernst Mach como mediador entre eles (GIDDENS, 1998, p. 181) e cinco características comuns aos três: 1) "a reconstrução

28 A palavra "misticismo" é utilizada ainda em uma terceira oposição por Comte: agora entre misticismo e idiotismo, isto é, excesso de subjetividade e excesso de objetividade (ou seja, o "empiricismo" que comentamos há pouco). Sem dúvida alguma, Comte estabelece uma identidade profunda entre os três usos da palavra "misticismo" e seus três pares de oposições (materialismo, empiricismo e idiotismo). Convém notar, mais uma vez: esses extremos intelectuais e psicológicos constituem pólos de que a razão normal deve manter-se distante - e a razão normal baseia-se no senso comum, como um meio-termo entre a teoria e a observação, entre a subjetividade e a objetividade. 
da história como realização do espírito positivo"; 2) "a dissolução final da metafísica, intimamente ligada à idéia de superação da própria filosofia"; 3) "a existência de um claro e definido limite entre o factual, o 'observável', e o imaginário, ou o 'fictício"; 4) "o 'relativismo' do conhecimento científico"; 5) "o vínculo integral entre ciência e moral e progresso material da humanidade" (idem, $\mathrm{p}$. 181-182). Já comentamos, por outras vias, as características 1 a 3; falta tratar das duas últimas.

Ao discutir o relativismo, como nos casos anteriores, Giddens apresenta corretamente as linhas gerais do pensamento comtiano, apenas para torcê-lo nos detalhes, em direção àquilo que ele, Giddens, considera incorreto. Já vimos o sentido do "relativo" comtiano, que está em oposição ao "absoluto": o ser humano não tem acesso às causas (primeiras e finais) nem a supostas "essências"; a única coisa passível de observação são relações entre fenômenos; tais relações são, por definição, as leis naturais. De acordo com Giddens, para Mach as "relações" são (ou devem ser) redutíveis a expressões matemáticas; obtidas essas expressões, as teorias são descartáveis, por serem inúteis; "apesar de isso diferir da visão de Comte, isso não está tão longe dela como pode parecer à primeira vista" (idem, p. 183), pois, "No positivismo de Comte, não era possível encontrar um lugar para o sujeito pensante: a psicologia nem mesmo aparecia na hierarquia das ciências e a noção de experiência subjetiva era encarada como uma ficção metafísica" (idem, p. 184). Deixando de lado o reiterado erro de imputar a Comte o projeto de matematização da sociedade e da análise sociológica, atribuir a Comte a negação da subjetividade humana é uma afirmação recorrente mas nem por isso correta. Comecemos pela lei dos três estados: ela afirma a capacidade humana de interpretar a realidade de acordo com diferentes princípios gerais, historicamente modificáveis; além disso, o conhecimento humano é um contínuo e eterno diálogo entre o interior (subjetivo) e o exterior (objetivo). Em termos epistemológicos, isso é um dos temas mais importantes e que, há séculos, oscila entre os objetivistas e os materialistas, mas que, para Comte, não é possível resolver de maneira categórica em que medida a subjetividade e a objetividade entram no conhecimento humano. Mas talvez seja a teoria da linguagem aquela parte das idéias comtianas que apresentam a refutação mais direta do comentário de Giddens: para Comte, a linguagem são os meios disponí- veis para o ser humano externar aquilo que está presente em seu interior (COMTE, 1890, v. II, cap. III); o que é esse "interior"? São sensações, sentimentos e idéias - em outras palavras, exatamente aquilo a que se dá o nome de "subjetividade", cuja existência, aliás, não é "metafísica".

Giddens também afirma que tanto Comte desprezava os "indivíduos" e as capacidades humanas que nem chegou a incluir a Psicologia na sua escala enciclopédica, isto é, que a teria concluído na Sociologia. Ora, a escala enciclopédica de Comte não parou na Sociologia, mas avançou mais um degrau: como Giddens considera apenas a Philosophie para seus comentários sobre Comte, ignora a Politique, em cujos volumes II e III Comte afirma não apenas a necessidade de fundar uma ciência dedicada ao ser humano individualmente tomado - nos termos de Comte, a "Moral", o que equivale, nos dias de hoje, à "Psicologia" -, como cria formalmente essa sétima ciência, acima da Sociologia. Convém notar que, se Comte não incluiu (inicialmente) a "Psicologia" na sua escala enciclopédica, foi porque a "Psicologia" de sua época (e mesmo muito do que há ainda hoje) era pura metafísica, a começar pelo "método" psicológico, que consistia na pura introspecção - em que o observador observava a si mesmo enquanto usava suas outras faculdades mentais, de modo que ao mesmo tempo observava e era observado (cf. COMTE, 1972; LAZINIER, 2002)29. Da mesma forma, a última obra de Comte, a Synthèse subjective, teria quatro volumes, dos quais o segundo e o terceiro tratariam de modo específico do estudo do ser humano individualmente considerado: entretanto, Comte morreu após publicar o primeiro desses quatro volumes ${ }^{30}$.

29 Ainda assim, podemos indicar dois livros brasileiros dedicados à "Psicologia" baseada em Comte: Escobar (1979) e Coelho (1982). Além dessas duas obras teóricas, houve toda uma escola de Psicologia Clínica baseada em Comte, a partir das pesquisas do médico paulista Aníbal da Silveira.

30 Somando o recurso às leis naturais à "ausência" de Psicologia, Giddens conclui que a Sociologia de Comte não apenas não é "reflexiva" como faz um apelo à "desresponsabilização" individual e coletiva, isto é, política. Nessa tese, Giddens foi seguido por Alcântara (2008): em Lacerda (2009b) apresentamos arrazoados demonstrando o erro de tais teses. Em todo caso, em Comte (1899, p. 45-60), afirma-se a necessidade de "consagrar para disciplinar" as forças sociais quaisquer e, para o que nos interessa, o indivíduo. 
Todavia, é necessário indicar que no capítulo I do volume IV da Politique, Comte distingue de maneira clara os "elementos sociais" (famílias, pátrias, humanidade e grupos intermediários) dos "agentes sociais". Essa distinção já fora esboçada no capítulo III do volume II, dedicado às famílias como elementos sociológicos, mas no volume IV Comte é formal na distinção entre uns e outros. $\mathrm{O}$ que caracteriza os "elementos sociais" é o fato de serem homogêneos em relação às sociedades, ou melhor, serem sociedades em escalas diversas: é por esse motivo que as famílias são a unidade sociológica e não os indivíduos. Já os "agentes sociais" são os responsáveis pela existência objetiva das sociedades e, mais do que isso, pelas ações concretas; o que caracteriza esses "agentes" é o exercício das suas "vontades" ("volontés"), que, embora livres em si, são submetidas às diversas condições e fatalidades sociológicas, biológicas e cosmológicas. Da mesma forma que nas teorias sociológicas contemporâneas (em que se incluem as do próprio Giddens), esses "agentes" são os indivíduos, com a particularidade de que, para Comte, a ação desses indivíduos deve conjugar a liberdade individual (a que se associa, necessariamente, a responsabilidade) e a convergência, isto é, a busca do benefício coletivo, direto ou indireto (cf. COMTE, 1890 , v. IV, p. 30-40). Sem forçar o argumento, e ao contrário do que afirma Giddens, é possível afirmar que em Comte há ao mesmo tempo a solução para uma forma de dualidade entre "agência" e "estrutura" e a definição de um indivíduo que, capaz de agir autonomamente, não se define pelo egoísmo, a partir dos modernos conceitos metafísicos (e, portanto, em última análise, teológicos) $)^{31}$.

A última característica que Giddens atribui a Comte é a íntima vinculação entre a ciência, por um lado, e o desenvolvimento moral e material da sociedade. Essa é uma mais ou menos elegante de afirmar que Comte foi um "cientificista" e, acima de tudo, um tecnocrata: quanto mais ciência, melhor desenvolvida a sociedade e mais "moralizada" ela será; a "moralidade" consistirá em variadas formas de intelectualismo, a serem racionalmente controladas. Vimos anteriormente como,

31 A respeito da gênese teológico-metafísica do individualismo moderno e de seu caráter egoísta, cf. Laffitte (1897, lições 5-6) e Dumont (1992, cap. 2). do ponto de vista político, Comte rejeitava o que chamamos atualmente de tecnocracia; contudo, importa aqui desfazer o nó que vincula ciência e desenvolvimento da moralidade. Para isso, cumpre definir o que é a moralidade, ou melhor, a moral para Comte: é o conjunto de atributos "afetivos" dos seres humanos, voltados para o benefício individual e, acima de tudo, coletivo. De modo mais específico, Comte determina dez "instintos" que originam as ações humanas, sete egoístas (voltados para a satisfação individual) e três altruístas (voltados para a colaboração e a satisfação dos outros); esses instintos são ordenados de acordo com sua força decrescente e sua dignidade crescente: instintos nutritivo, sexual, materno, destrutivo, construtivo, orgulho e vaidade (como egoístas), apego, veneração e bondade (como al-

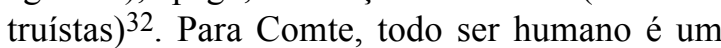
indivíduo e um membro de uma sociedade; cada sociedade, por sua vez, estimula mais alguns instintos e desenvolve menos (ou reprime) outros. $\mathrm{O}$ desenvolvimento moral, nesse quadro, consiste no fortalecimento dos instintos altruístas e na compressão (e nunca na extinção) dos instintos egoístas - ou, nos termos de Comte, no desenvolvimento da ternura (altruísmo) e da pureza (compressão do egoísmo).

Do ponto de vista histórico, o relacionamento entre egoísmo e altruísmo variou. De uma perspectiva de longuíssima duração, o desenvolvimento material permite que a pressão das necessidades individuais diminua e, portanto, que o altruísmo seja desenvolvido. Sem dúvida alguma que a ciência, como conhecimento da realidade, tem um papel central nisso, mas o longo acumular de produtos humanos (materiais, intelectuais, artísticos etc.) é o fator-chave aí, de modo que o desenvolvimento moral é possível e até se realiza antes de a ciência constituir-se como tal.

De acordo com a filosofia da história de Comte, o Ocidente apresenta uma inversão im-

32 Esses dez "instintos" somam-se a cinco funções intelectuais e a três da ação prática; esse conjunto de 18 funções cerebrais constitui a "alma", na teoria comtiana. Notese que o móvel das ações são os instintos, que visam à sua satisfação; a inteligência (modernamente representada de maneira sintética pela ciência) ocupa um papel apenas instrumental aí. Não é difícil de perceber que essa teoria da alma - desenvolvida no longo capítulo III do volume I da Politique (COMTE, 1890, v. I, cap. III) - é uma teoria da agência humana. 
portante. Após a Grécia ter desenvolvido a inteligência (a arte, a filosofia e a ciência), os romanos desenvolveram a atividade prática (subordinando a inteligência à ação e criando uma vasta civilização pacificada, ao redor do Mediterrâneo), faltava o desenvolvimento da moralidade - o que se realizou na Idade Média, católico-feudal, mais por meio dos hábitos cavalheirescos que por meio do dogma católico. Independentemente das relações estabelecidas entre egoísmo e altruísmo nesse período, é fácil perceber como não houve relação direta entre desenvolvimento científico e desenvolvimento moral no período. Aliás, para Comte - e bem ao contrário do que afirma Giddens -, o período posterior à Idade Média (chamado por Comte de "modernidade") consiste em um desenvolvimento contínuo da inteligência em reação à moralidade católica; considerando que, para Comte, a moral católica é egoísta, até certo ponto faz sentido essa reação, mas o combate ao catolicismo tornou-se combate generalizado à moral como um todo. Além disso, inúmeras teorias científicas afirmam o materialismo, que é a subordinação de fenômenos mais nobres aos mais grosseiros: além de negarem as particularidades do ser humano (em termos sociais e morais), há teóricos que afirmam o caráter intrinsecamente egoísta do homem, negando o altruísmo (Hobbes é um bom exemplo, mas também os "economistas políticos"). Dessa forma, não há relação causal entre "desenvolvimento da ciência" e "desenvolvimento moral" da humanidade, no pensamento comtiano.

Como se vê, portanto, a argumentação de Giddens é frágil e enviesada; baseado em uma leitura superficial de apenas uma obra de Comte (a Philosophie), o conjunto da argumentação de Giddens cria um Augusto Comte cientificista e tecnocrático; caso considerasse com seriedade as outras obras de Comte (em particular, a Politique), seria difícil sustentar tais opiniões: é essa a grande virtude dos autores que recuperam Comte, de que trataremos em seguida ${ }^{33}$.

33 Embora já tenhamos indicado, na primeira seção deste artigo, que Giddens não é o único autor a criticar de maneira sistemática Augusto Comte, convém realçar aqui tal fato; as críticas elaboradas pela Escola de Frankfurt, em particular as surgidas durante e após a "polêmica do Positivismo na Sociologia alemã", exigem uma análise toda própria.

\section{O RECUPERAR DE COMTE}

Em um artigo que visa a tratar de obras recentes sobre Augusto Comte, talvez tenha causado estranheza as longas observações feitas acima. Esse procedimento justifica-se pelo seguinte motivo: enquanto as obras de que trataremos na seqüência apresentam esse pensamento social (em todo ou em partes), sem considerar as críticas anteriores - mas sabendo que elas existem -, as críticas correntes teriam que ser, em algum momento, enfrentadas. Além disso, o valor da "recuperação" aumenta quando se tem em mente a envergadura da "perda".

Compreender o pensamento de Augusto Comte em si mesmo e em sua inteireza (ainda que sem tratar de todo ele), deixando de lado o rótulo fácil de "positivista", conforme o senso comum acadêmico contemporâneo estabelece, e perceber os elementos que o fundador do Positivismo apresenta para as questões atuais - em outras palavras, não incorrer nos diversos problemas teóricos e metodológicos discutidos até aqui: esses são os elementos que unem os livros de Juliette Grange (1996), Sérgio Tiski (2007) e Laurent Fédi (2008). A procedência nacional dessas pesquisas é significativa: a maior parte delas é francesa (Grange e Fédi), enquanto poucos são brasileiros (Tiski); embora não tratemos de nenhum anglófono aqui, o fato é que autores de língua inglesa ocupam uma posição intermediária ${ }^{34}$. Evidentemente, esses três livros não esgotam a fortuna crítica relativa a Comte; da segunda metade do século XX para cá poderíamos também indicar diversos pesquisadores que consideraram o "Positivismo" sem a camada crítica apontada antes: Kremer-Marietti (1980), Aron (1999), Arnaud (1969), Bastide (1990), Lacroix (2003) e, no Brasil, Soares (1999), Ribeiro Jr. (2006) e Trindade (2007). O que distingue dos demais os três livros que nos interessam aqui, além das datas de publicação mais recentes, é a consciência das críticas com que lidamos há pouco; é tendo essas críticas como pano de fundo que os autores de que nos ocuparemos

\footnotetext{
34 Podemos incluir no rol anglófono o pequeno mas interessante livro de Mike Gane (2006), que historia as várias formulações da "lei dos três estados", e as muitas pesquisas de Mary Pickering, responsável por uma alentada biografia intelectual de Comte, cujo volume segundo está prestes a ser lançada pela editora de Cambridge, embora o volume primeiro seja de 1993.
} 
escrevem; nesse sentido, é comum, e infelizmente cansativo, ler afirmações no sentido de que cumpre recuperar o pensamento de Comte, em primeiro lugar lendo a obra no original e, em segundo lugar, em seus próprios termos (cf. GRANGE, 1996, p. 9-11; FÉDI, 2008, Prefácio).

O mais ambicioso é o de Juliette Grange, que consiste em uma apresentação sistemática da obra de Comte. Com quase 450 páginas em letra pequena, a autora retraça os argumentos comtianos de acordo com a seqüência em que foram elaborados, isto é, começando pela discussão teóricometodológica sobre as ciências, com o fito de apresentar a Sociologia; em seguida, tira as conseqüências políticas e as aplicações práticas das perspectivas teóricas, ao mesmo tempo que ilumina como essas preocupações concretas influenciaram as teorizações; no final do livro, estabelece a relação dessas idéias preliminares com a de religião. Com uma grande quantidade de citações diretas e dialogando com questões atuais (ecologia, empirismo, pacificismo, "império", mundialização, economicismo, holismo etc.), o livro permite uma compreensão ao mesmo tempo aprofundada de Comte e indicativa de sua atualidade. Esses elementos permitem que o livro seja uma excelente introdução a Comte, em particular porque o todo de sua obra é analisado (superando a afirmação da própria autora, de que "ninguém lê o conjunto das obras" (GRANGE, 1996, p. 9)).

A organização didática do livro, de acordo com um princípio mais ou menos cronológico, não impede a autora de (r)estabelecer a todo instante as interconexões entre problemas epistemológicos, científicos, sociológicos, políticos, psicológicos e artísticos que Augusto Comte estabelecia ao escrever. Isso, sem dúvida, acarreta uma pequena dificuldade: o raciocínio é pleno de vaivéns, em que, à medida que se avança na exposição, a quantidade de pressupostos teóricos e metodológicos aumenta, exigindo tanto do autor quanto do leitor grande concentração e necessidade de abstração (ainda que essa dificuldade seja atenuada pela repetição dos elementos importantes quando as discussões exigem-no).

O estilo da autora merece algumas observações. Em forma literária, a exposição apresenta a todo instante perguntas-chave, por vezes retóricas, por vezes realmente importantes: "Que é uma obra representativa?", "O Positivismo é um fisicalismo?", "A filosofia de uma ciência ultrapassada?", "Filó- sofo do século XXI?". É claro que essa forma de expor facilita a compreensão, quando menos porque formula com clareza as questões que orientam os raciocínios. Além disso, a inspiração propriamente literária tende à exposição por meio de contradições, o que dificulta um tanto a leitura e a evolução das idéias. Poder-se-ia argumentar que se trata de um artifício utilizado para, além de expressar um estilo de redação, também permitir a adoção de várias perspectivas e a constatação de pontos fracos ou falhos na matéria exposta.

O livro de Grange procura expor o pensamento profundo de Comte - "oculto", segundo suas palavras (idem, p. 10-11) - deixando de lado o senso comum e a referência a aspectos propriamente datados. Assim, por exemplo, ela comenta: "Trata-se bem, todavia, de reler um texto [...] fora dos destinos ulteriores que múltiplas posteridades institucionais ou ideológicas forjaram [...]. A história da palavra positivismo o destino singular dessa obra, pouco comentada em si, que forneceu diversos neologismos para a linguagem comum neologismos cuja acepção usual contradiz freqüentemente o sentido proposto por Comte. É por essa razão que será de fato preferível evitar o uso da palavra 'positivismo', o grande peso de seu uso trivial levando-nos a preferir a de 'comtismo' [...]" (idem, p. 29-30).

Da mesma forma, na seção intitulada "O Positivismo é um fisicalismo?" (idem, p. 77-81), a autora faz referência direta às costumeiras aproximações da obra de Comte com a dos vários membros do Círculo de Viena (em particular com as doutrinas de Rudolph Carnap, autor da expressão "fisicalismo") para, após uma densa discussão epistemológica, concluir que "O positivismo não é nem um realismo, nem um fisicalismo: é um historicismo" (idem, p. 81): nesse historicismo, ou melhor, nessa epistemologia historicista, o ser humano vive em uma realidade que o cerca e que o constrange, mas que é também modificável por esse mesmo ser humano, a partir do conhecimento abstrato, parcial e relativo das regularidades; esse conhecimento muda de acordo com a sociedade e, em particular, de acordo com a acumulação histórica, em que as elaborações teóricas (isto é, científicas) são feitas a partir de uma conjugação entre necessidades sociais, a realidade concreta e, claro, a subjetividade de cada pesquisador. Na seqüência, aliás, a autora discute precisamente a historicidade do conhecimento (aí incluído o científico, mas to- 
mado em sentido geral), para indicar que, para Comte, essa historicidade refere-se, mais que a um caráter temporário (como em certo sentido insistiu, por exemplo, Weber, em A ciência como vocação (WEBER, 1977)), às vinculações que o conhecimento tem com as sociedades que o produz, assim como à necessidade de acumular observações, teorias e perspectivas ${ }^{35}$.

Mas o mais interessante no livro de Grange é que a discussão epistemológica não se confina em si mesma, mas é apresentada - de acordo com o espírito da obra comtiana - como condição intelectual para considerações sociológicas e políticas mais amplas: o que chamamos hoje de "Epistemologia" e de "Filosofia das Ciências (Sociais)" integra um exame mais geral da realidade humana, com vistas à intervenção nessa mesma realidade. Assim, não apenas esse gênero de discussão ocupa apenas entre um quarto e um terço do livro, como ele subordina-se sempre às considerações sociais. Talvez afirmar a "subordinação às considerações sociais" pareça óbvio para um cientista social, mas é necessário ter em mente o senso comum a respeito de Comte ou do "Positivismo", em que ambos são percebidos apenas em termos epistemológicos e estritamente "cientifistas".

Dessa forma, a autora tem em mente as idéias profundas da Sociologia e da política comtianas, mostrando o sentido da "lei dos três estados" como sendo, mais que propor a "morte de deus", a afirmação de uma sociedade plenamente humana e caracterizada pelo conhecimento científico e imanente da realidade, além de pacífica e globalizada (idem, p. 8-41, 421-423 et passim) ${ }^{36}$. A partir dessa perspectiva, outros aspectos são comentados, alguns deles com bastante insistência: a incorporação do fetichismo no Positivismo, que a autora denomina de "neofetichismo" (idem, p. 129-136, 357-

\footnotetext{
35 Nesse sentido, Comte abarca as idéias de Thomas Kuhn, sem cair nos problemas criados pelo conceito de "paradigma" (em particular, a incomensurabilidade mútua dos paradigmas)

36 Considerando dessa perspectiva o empreendimento científico, a criação da sétima ciência por Comte - a "Moral" - que, como outros elementos do seu pensamento, é tão facilmente desdenhável - assume um aspecto bastante atual, na forma da regulação social e ética das pesquisas científica
}

370), as relações entre indivíduo e sociedade (idem, p. 267-276), a regulação prática (isto é, política) da sociedade (idem, parte II, cap. V-VI). A conclusão geral da autora é que, embora vários aspectos epistemológicos, científicos, sociológicos e políticos de Comte sejam inevitavelmente datados e embora seu estilo dificulte, sem dúvida, a compreensão, o seu pensamento, isto é, a inspiração profunda e as questões que ele formulou são atuais, são as nossas (idem, p. 19-21, 421-423 et passim).

O livro de Fédi (2008) é, assim como o de Grange, uma apresentação didática do pensamento de Comte e igualmente realiza uma exposição das idéias comtianas preocupando-se em indicar sua "atualidade". Com pouco menos de 200 páginas, a edição original é do ano 2000 e segue um roteiro até certo ponto tradicional: ciências e filosofia das ciências; sociedade e Sociologia; religião e política. Sua brevidade não diminui a qualidade da apresentação, pois, embora o autor cite o original, está mais preocupado em compreender e expor a lógica subjacente do pensamento comtiano (em particular daquela mais madura, isto é, do Système de politique positive e da Synthèse subjective) que em apresentar passo a passo a constituição desse pensamento. Isso confere grande agilidade à narrativa, que pode ser feita com facilidade em um ou dois dias de leitura contínua.

Fédi discute com clareza várias das questões que comentamos nas seções anteriores; ao mesmo tempo em que reconstitui as características da obra comtiana, articula-as com questões mais contemporâneas: a importância da afetividade e da subjetividade para o ser humano em geral e para a prática científica em particular (aí incluída a incorporação do fetichismo na positividade) (idem, p. 35-87, 145-151); o relativismo específico ao espírito positivo (idem, p. 74-78); a deontologia pacifista da sociedade moderna (idem, p. 137-144); a inclusão social (idem, p. 100-104); a separação entre Igreja e Estado e, por extensão, a crítica ao que chamaríamos hoje de "totalitarismo" e de "tecnocracia" (idem, p. 172-175).

Francamente simpáticos a Comte, tanto Grange quanto Fédi preocupam-se mais em resgatar um pensamento que consideram instigante que em fazer-lhe a crítica. É interessante notar que uma qualidade de ambos os livros é que esse resgate, essa "apresentação geral" do pensamento comtiano não é feita às custas da fluência do texto; em outras palavras, não se tratam de apresentações por assim 
dizer burocráticas, mas de exposições vivas, que, por sua própria forma, tornam mais fácil a resposta à necessária pergunta a respeito da "atualidade" do pensamento de Comte. Grange considera que o projeto religioso de Comte, em si, é impossível; mas, por outro lado, as críticas que Comte fez ao individualismo, ao racionalismo, ao desregramento científico, ao absolutismo filosófico, assim como a defesa da liberdade de pensamento e de expressão, da separação entre Igreja e Estado e do primado do "social" em relação ao "econômico" são elementos permanentes (GRANGE, 1996, p. 421422); mais do que isso, logo no início do livro ela afirma que "[...] em grande medida, vivemos em um mundo quase inteiramente previsto por Comte" (idem, p. 19). Fédi, da sua parte, considera que a obra de Comte deve ser lida "[...] não na esperança irrisória de reabilitar Comte ou de impor dogmaticamente suas soluções, mas simplesmente tendo em vista levar suas reflexões à discussão, com a convicção de que o interesse dessa filosofia pode se renovar à medida que surjam novos problemas" (FÉDI, 2008, p. 168) 37.

Por fim, o livro do brasileiro Sérgio Tiski (2006) é mais específico, tratando de uma questão central em Comte: a religião. Esse tema é importante seja a partir do enunciado comtiano da "lei dos três estados" (segundo a qual as concepções humanas passam por três fases sucessivas - teológica, metafísica e positiva), seja porque a fase final de Comte caracterizou-se pela fundação da "Religião da Humanidade", seja porque são várias as referências à contradição entre a lei dos três estados e a Religião da Humanidade.

O procedimento que Tiski adotou foi adequado para sua proposta: verificar de que maneira, ao longo de sua carreira, Comte considerou o conceito de (e, portanto, a palavra) "religião", bem como os conceitos associados de "teologia" e "deus". Examinando do ponto de vista cronológico a obra comtiana, Tiski dividiu-a em quatro fases, que passam de uma adesão à fé católica (17981812) à emancipação com respeito à teologia (1817-1848) até a criação da Religião da Humanidade (1848-1857), de caráter humano; entre o

37 Convém notar que Fédi tem participado, juntamente com Catherine Kintzler e outros, dos vivos debates recentes sobre a laicidade na França, citando Comte como uma das suas referências. Cf. Fédi (2007) e Kintzler (2008). catolicismo e a emancipação, Tiski identifica uma fase intermediária, de oscilação entre a emancipação humanista com o uso de expressões teológicas (1812-1817). Ao investigar tanto os livros quanto a extensa correspondência de Augusto Comte (em oito volumes), o autor identificou cada uma das vezes em que o francês usou as expressões indicadas acima, determinando o sentido adotado; da mesma forma, há grande quantidade de citações diretas de Comte, o que enriquece sobremaneira o texto.

A idéia de religião em Comte, de fato, é central. Como demonstra Tiski, enquanto em um primeiro momento Comte identificava religião e teologia, isto é, considerava que a religião é a crença no sobrenatural, em vontades externas ao ser humano que comandariam arbitrária e absolutamente a realidade (e a que se oporia a ciência, de caráter relativo), em sua fase mais madura Comte percebia na religião uma forma de unidade humana. Essa unidade seria ao mesmo tempo "moral" (de caráter individual, em que ocorreria a harmonia afetiva, intelectual e prática) e coletiva (em que os indivíduos e os grupos sociais relacionar-se-iam de maneira construtiva e pacífica) e de que a teologia teria sido apenas uma forma de realização, temporária e transitória entre o fetichismo (estágio inicial do ser humano) e o positivismo (estágio final). Assim, a religião são é a prática e a instituição sociais que denotam a totalidade da existência humana, no pensamento comtiano.

As várias acepções que a "religião" teve no pensamento de Comte são um bom índice das mudanças por que esse pensamento atravessou. Sem esposarmos a tese da ruptura entre essas fases - em particular entre a Philosophie e a Politique -, é possível identificar uma inflexão de um certo "cientificismo" - que, talvez, seja melhor qualificado de "intelectualismo" - para um subjetivismo afetivo baseado no conhecimento científico.

Ao realizar tal investigação, Sérgio Tiski é exaustivo e minucioso. Embora isso torne a leitura um tanto cansativa, o resultado é satisfatório, pois tornam-se claros vários elementos: a continuidade na carreira de Comte; as relações teóricas, epistemológicas e políticas da "religião", da teologia e da "positividade"; a possibilidade de um a religião humana e humanista.

Há alguns aspectos problemáticos, todavia, no livro de Tiski; esses problemas não comprometem a investigação realizada, mas produzem re- 
sultados estranhos na argumentação do autor e, no final das contas, na própria compreensão do pensamento comtiano. Por um lado, há aspectos estilísticos do texto no mínimo desconcertantes, que geram uma dubiedade na interpretação que dificulta a compreensão e a apreensão dos argumentos pelos leitores. Essa dubiedade é caracterizada pelo uso recorrente de expressões com o símbolo gráfico da barra (“/”) e indicam que o autor não se decidiu a respeito de qual a interpretação que adotaria. Exemplos aleatórios e não exaustivos: "Os três últimos volumes (lições 46 a 60) são dedicados à Sociologia/moral/política" (idem, p 160); "[...] supondo a transitividade/ sinonímia entre os dois termos" (idem, p. 194); "E, referindo-se à unidade, harmonia conseguida a partir de sua experiência de amor por Clotilde de Vaux, unidade/harmonia que se tornaram ' $[. .$.$] uma$ das bases [...]"” (idem, p. 226); “[...] ao mesmo tempo a justificação/legitimação da legitimação da humanidade" (idem, p. 246); “[...] são explicitadas as duas funções/finalidades/destinações da religião [...]" (idem, p. 252).

Um segundo problema na interpretação de Tiski refere-se à forma como apreende - e, portanto, expõe - o conceito de "religião" em Comte, ou seja, refere-se ao próprio objeto de sua investigação; nesse sentido, é um problema mais central. O conjunto da pesquisa de Tiski é satisfatório no sentido de indicar que Augusto Comte modificou suas concepções a respeito da "religião", em particular entre as fases da Philosophie e da Politique, que correspondem às terceira e quarta fases identificadas pelo autor ${ }^{38}$. Enquanto na primeira dessas duas Comte adotava como sinônimo de "religião" a teologia, na segunda fase passou a distinguir uma coisa da outra, considerando que a religião é um estado de unidade e harmonia moral e social, do indivíduo e dos grupos humanos e de que a teologia é apenas uma das modalidades possíveis (e histórica e logicamente transitória). Assim, na fase final de Comte, há a afirmação da religião, mas agora humana e humanista: daí o nome de "Religião da Humanidade".

Ora, mesmo considerando que o conceito de "religião" para Comte modificou-se ao longo do

38 As duas primeiras correspondem às da infância e da adolescência, o que, embora biograficamente sejam mais ou menos relevantes, não têm de fato nenhuma importância para a obra filosófica da maturidade. tempo e que em sua obra mais madura ele possuía uma definição bastante particular e distante do senso comum, é precisamente esse sentido do senso comum (que toma como equivalente de religião a teologia) que norteia a avaliação de Tiski. Basta notar os segintes comentários da investigação: na "Introdução", o autor afirma de maneira simples, direta e reveladora que "Utilizamos o termo religião no seu significado mais comum, conforme aparece nos três trechos a seguir"; em seguida cita três dicionários vernaculares e resume: "Como se pode notar, a pressuposição básica na noção comum de religião é a existência da divindade, e a necessidade e a possibilidade de relacionamento com ela, que explica e decide a sorte do homem. [...] Uma grande porção da humanidade continua, de um modo ou de outro, sendo religiosa nesse sentido tradicional, isto é, acreditando em divindade sobrenatural e sendo, portanto, sobrenaturalista. O sobrenaturalismo é comum e estamos acostumados a ele" (idem, p. 1-2). Embora reconheça logo em seguida (idem, p. 3-5) a confusão que se produz na compreensão de Comte o uso desse sentido de senso comum a respeito da "religião" - e, como vimos, consistindo exatamente na explicação desses sentidos específicos o objeto de sua pesquisa -, em outros trechos o autor reafirma o senso comum. Vejamos uma passagem decisiva, nesse sentido: “É óbvio que com o 'theos' humanidade e com a religião da humanidade $A$. Comte retorna a um teísmo e a uma teologia, além de retornar a uma religião. Do mesmo modo, com a sua 'filosofia primeira'39 esboçada, prometida mas não escrita, ele retorna a uma metafisica. [...] A sua 'metafisica', o seu 'teísmo' e a sua 'teologia' são muito diferentes do tradicional, sobretudo pela restrição ao humano, ao natural e ao científico; nesse sentido, o não assumir e o não utilizar tais termos evitou toda a confusão [...]. [...] A sua 'filosofia primeira' é uma 'metafísica', uma espécie de metafisica; o seu humanismo é um 'teísmo'; e a sua 'teoria da humanidade' uma 'teologia"' (idem, p. 241; sem grifos no original). Por fim, no último parágrafo do livro: "Teísmo, só que humano: humanismo" (idem, p. 336).

39 Seguindo uma sugestão de Francis Bacon, a "fillosofia primeira" de Comte consiste no conjunto de pressupostos e procedimentos teóricos e epistemológicos do Positivismo (cf. COMTE, 1934, p. 479; cf. também LAFFITTE, 1894; 1928). 
A insistência de Tiski em adotar o senso sentido comum para a exposição das idéias de Comte gera confusão e dificulta o entendimento do que ele mesmo, Tiski, pesquisa e expõe. Em um momento, afirma que não se pode compreender Comte a partir do senso comum; em seguida, retoma o mesmo sentido comum para expor as idéias de Comte. Essa hesitação teórica não deixa de ser uma variação, mais profunda, do problema anteriormente indicado, isto é, do uso do sinal gráfico da barra em sua exposição. Por outro lado, não se trata apenas de uma questão terminológica, isto é, de palavras sendo trocadas, mas de conceitos sendo misturados: como vimos anteriormente, e como o próprio Tiski esclarece, a teologia (assim como a metafísica) pressupõe o absolutismo filosófico e a pesquisa das causas, enquanto a positividade requer o relativismo e a busca das regularidades, cada qual com profundas implicações sociais (guerra versus pacifismo, confusão entre Igreja e Estado versus separação entre Igreja e Estado, escravidão versus trabalho livre etc.).

Esse problema - a hesitação teórica - de fato dificulta a compreensão; por outro lado, embora exija do leitor um esforço redobrado para compreender uma argumentação que, por si só, é densa, o conjunto da pesquisa não é comprometido: abstraindo-se dessas dificuldades, o resultado é satisfatório.

\section{COMENTÁRIOS FINAIS}

Em outra ocasião (LACERDA, 2008a) afirmamos que cumpre recuperar Augusto Comte como um clássico sociológico, de acordo com a definição de Jeffrey Alexander (1996), isto é, como um autor capaz de fornecer quadros mentais, descrições sociológicas, juízos de valor e modelos de procedimentos que inspirem e orientem, de maneira viva e efetiva, gerações de pesquisadores e pensadores. É corrente afirmar que Augusto Comte é um "clássico" da Sociologia (e, de maneira mais ampla, das Ciências Sociais e Humanas), mas tal classificação serve mais para incluílo em um escaninho estereotipado que para servirmo-nos efetivamente dele.
Parafraseando o líder revolucionário francês Georges Danton, Comte afirmava que "só se destrói o que se substitui" (COMTE, 1899, p. 191): não deixou de ser esse o percurso deste artigo. A fim de indicar as contribuições recentes de pesquisadores que apresentam um Comte "clássico" (no sentido de Alexander), foi necessário antes comentar vários mitos e interpretações erradas a seu respeito. Como indicamos anteriormente, a escolha de Giddens como autor preferencial para a crítica deve-se ao duplo motivo de ser ele o autor da narrativa-padrão atual da história da Sociologia - narrativa que, a respeito de Comte, apresenta sérias deformações que, longe de serem inocentes, produzem um resultado teórico e prático funesto. Mas, sem dúvida, outras tantas observações poderiam ser feitas a propósito de outros críticos e comentadores, de que a Escola de Frankfurt e mesmo alguns marxistas são bons exemplos. Não se trata de integrar o debate teórico e metodológico próprio às disciplinas científicas, mas, antes, de evitar um senso comum acadêmico mais preocupado com a repetição mecânica de estereótipos que com a reflexão séria do pensamento de autores - mesmo, e talvez principalmente, daqueles de quem se discorda.

É claro que muitas das críticas direcionadas a Comte são substantivas e, mesmo sem necessariamente concordar com elas, referem-se a diferenças reais entre as várias correntes de pensamento social e político; mas não deixa de ser irônico o fato de que, como se pode constatar com os livros de Grange, Fédi e Tiski, muitas das críticas feitas ao pensamento que se atribui a Comte são, na verdade, compartilhadas pelo mesmo que é criticado.

Dessa forma, o escrutínio dessa discussão é altamente instrutivo; poder-se-ia, quem sabe, falar-se em uma "Sociologia das Ciências Sociais" com um "estudo de caso: Comte e seu(s) legado(s)". Trata-se não apenas de recuperar um pensamento rico, amplo e sugestivo - literalmente fundamental -, mas também de evitar automatismos mentais, em que a criatividade e a criticidade recuperam o espaço perdido para a rotulação estereotipada das correntes de pensamento.

Gustavo Biscaia de Lacerda (gblacerda@ufpr.br) é Doutorando em Sociologia Política pela Universidade Federal de Santa Catarina (UFSC), Sociólogo da Universidade Federal do Paraná (UFPR), bolsista do Conselho Nacional de Desenvolvimento Científico e Tecnológico (CNPq) e Editor-Executivo da Revista de Sociologia e Política. 


\section{REFERÊNCIAS BIBLIOGRÁFICAS}

ALCÂNTARA, F. H. C. 2008. Os clássicos no cotidiano. $3^{\mathrm{a}}$ ed. São Paulo : Arte e Ciência.

ALEXANDER, J. 1996. A importância dos clássicos. In : GIDDENS, A. \& TURNER, J. (orgs.). Teoria Social hoje. São Paulo : UNESP.

ARANA, H. G. 2007. Positivismo - reabrindo o debate. São Paulo : Autores Associados.

ARNAUD, P. 1969. Pour connaître la pensée d'A. Comte. S/1 : Bordas.

ARON, R. 1999. As etapas do pensamento sociológico. $3^{\mathrm{a}}$ ed. Lisboa : Dom Quixote.

AYER, A. J. (ed.). 1959. Logical Positivism. New York : Free.

BAKUNIN, M. 2001. Escritos contra Marx. São Paulo : Imaginário.

BASTIDE, P.-A. 1990. A grande iniciação do proletariado. In : COMTE, A. Discurso sobre o espírito positivo. São Paulo : M. Fontes.

BOBBIO, N. 2001. O positivismo jurídico. Lições de Filosofia. São Paulo : Ícone.

BOURDIEU, P. 2004. Os usos sociais da ciência. Por uma Sociologia clínica do campo científico. São Paulo : UNESP.

COELHO, L. M. S. 1982. Fundamentos epistemológicos de uma Psicologia Positiva. São Paulo : Ática.

COMTE, A. 1890. Système de politique positive ou traité de Sociologie instituant la Religion de l'Humanité. $3^{\text {ème }}$ ed. 4 v. Paris : Larousse.

1895. La philosophie positive d'Auguste Comte, condensée par Miss Harriet Martineau. Paris : L. Bahl.

1899. Apelos aos conservadores. Rio de Janeiro : Igreja Positivista do Brasil.

1934. Catecismo positivista, ou sumária apresentação da Religião universal. $4^{\mathrm{a}} \mathrm{ed}$. Rio de Janeiro : Apostolado Positivista do Brasil.

1957. A General View of Positivism. New York : R. Speller.

1972. Terceiro opúsculo (maio de 1822) : Plano dos trabalhos científicos necessários para reorganizar a sociedade. In : Opúsculos de filosofia social. São Paulo : USP.
1990. Discurso sobre o espírito positivo. São Paulo : M. Fontes.

2000. Synthèse subjective ou système universel des conceptions propres a l'état normal de l'Humanité. Paris : Fayard.

DUMONT, L. 1992. Essays on Individualism. Modern Ideology in Anthropological Perspective. Chicago : University of Chicago.

DUTRA, L. H. A. 2005. Oposições filosóficas. A Epistemologia e suas polêmicas. Florianópolis : UFSC.

ESCOBAR, C. 1979. Aos psiquiatras e aos nervosos. Bases para uma Medicina consensual. Rio de Janeiro : Cátedra.

FÉDI, L. 2007. L'utopie laïque. Disponível em : http://www.mezetulle.net/article6009567.html. Acesso em : 11.ago.2009.

. 2008. Comte. São Paulo : Estação Liberdade.

GANE, M. 2006. Auguste Comte. London : Routeledge.

GIDDENS, A. 1982. Sociology. A Brief but Critical Introduction. New York : Harcourt.

1998. Comte, Popper e o Positivismo. In : . Política, Sociologia e Teoria Social. São Paulo : UNESP.

2000. Augusto Comte e o Positivismo. In: . Em defesa da Sociologia. Ensaios, interpretações e tréplicas. São Paulo : UNESP.

GIDDENS, A. \& PIERSON, C. 1998. Conversas com Anthony Giddens. O sentido da modernidade. Rio de Janeiro : Fundação Getúlio Vargas.

GRANGE, J. 1996. La philosophie d'Auguste Comte. Science, politique, religion. Paris : PUF.

HALFPENNY, P. 1982. Positivism and Sociology : Explaining Social Life. London : G. Allen \& Unwin.

HALLER, R. 1990. Wittgenstein e filosofia austríaca. São Paulo : USP.

KINTZLER, C. 2008. Qu'est-ce que la laïcité? $2^{\mathrm{e}}$ ed. Paris : Vrin. 
KOLAKOWSKI, L. 1976. La philosophie positiviste. Science et philosophie. Paris : D. Gonthier.

KREMER-MARIETTI,A. 1980. Le projet anthropologique d'Auguste Comte. Paris : SEDES.

LACERDA, G. B. 2003. A república positivista : um projeto radical de liberdade e fraternidade. In : LACERDA NETO, A. V. A república positivista. Teoria e ação no pensamento político de Augusto Comte. $3^{\mathrm{a}}$ ed. Curitiba : Juruá.

2004. Elementos estáticos da teoria política de Augusto Comte : as pátrias e o poder Temporal. Revista de Sociologia e Política, Curitiba, n. 23, p. 63-78, nov. Disponível em : http://www.scielo.br/pdf/rsocp/n23/ 24622.pdf. Acesso em : 21.nov.2008.

2008a. Dois erros sobre a doutrina política comtiana : "autoritarismo" e "funcionalismo público". Espaço Acadêmico, Maringá, ano VIII, n. 87, ago. Disponível em : http:// www.espacoacademico.com.br/087/ 87lacerda.htm. Acesso em : 10.11.2008.

2008b. Eqüidade no projeto republicano de Augusto Comte. Artigo apresentado no $6^{\circ}$ Encontro da Associação Brasileira de Ciência Política (ABCP), realizado em Campinas, entre 29 de julho a $1^{\circ}$ de agosto. Digit. Disponível em : http://201.48.149.88/abcp2008/arquivos/22_7_2008_17_23_19.pdf . Acesso em : 10.nov.2008.

2009a. As críticas de Augusto Comte à Economia Politica. Artigo apresentado no I Seminário Nacional de Sociologia Econômica, realizado entre 19 e 22 de maio, em Florianópolis. Digit.

2009b. Augusto Comte "no cotidiano". Disponível em : http://filosofiasocialepositivismo.blogspot.com/2009/05/augustocomte-no-cotidiano.html. Acesso em : 15.6.2009.

LACERDA NETO, A. V. 2003. A república positivista. Teoria e ação no pensamento político de Augusto Comte. $3^{a}$ ed. Curitiba : Juruá.

2004. A desinformação antipositivista no Brasil. Curitiba : Vila do Príncipe.
LACROIX, J. 2003. A Sociologia de Augusto Comte (o fundador da Sociologia). Curitiba : Vila do Príncipe.

LAFFITTE, P. 1894. Cours de philosophie première. T. II : des lois universelles du monde. Paris : Société Positiviste.

1897. Le catholicisme. Paris : Société Positiviste.

1928. Cours de philosophie première. T. I : théorie positive de l'entendement. Paris : Société Positiviste.

LAZINIER, E. 2002. La Psychologie d'Auguste Comte. Disponível em : http:// membres.lycos.fr/clotilde/articles/ psychoac.htm. Obtido em : 27.ago.2008.

LÉVI-STRAUSS, C. 2008. La pensée sauvage. In : Gallimard.

PETIT, A. (dir.). 2003a. Auguste Comte. Trajectoires positivistes, 1798-1998. Paris : L'Harmattan.

(dir.). 2003b. Auguste Comte aujourd'hui. Paris : Kimé.

PICKERING, M. 1993. Auguste Comte - An Intellectual Biography. Cambridge : Cambridge University.

REIS, J. C. 2004. A História entre a Filosofia e a Ciência. $3^{\mathrm{a}}$ ed. São Paulo : Autêntica.

RIBEIRO JR., J. 2006. Augusto Comte e o Positivismo. Campinas : Edicamp.

SALMON, W. C. 1969. Lógica. Rio de Janeiro : Zahar.

SERRAT, P. T. M. 1983. Profilaxia da neurose. Curitiba : $\mathrm{s} / \mathrm{n}$

SKINNER, Q. 2002. Visions of Politics. V. I : Regarding Method. Cambridge : Cambridge University.

SOARES, M. P. 1999. O Positivismo no Brasil. 200 anos de Augusto Comte. Porto Alegre : UFRS.

TISKI, S. 2006. A questão da moral em Augusto Comte. Londrina : UEL. 
TORRES, A. 1997. O léxico de Augusto Comte. Criptografia e filosofia. Rio de Janeiro. Dissertação (Mestrado em Filosofia). Universidade Estadual do Rio de Janeiro.

TRINDADE, H. 2007. O Positivismo. Teoria e prática. $3^{\mathrm{a}}$ ed. Porto Alegre : UFRS.
WACQUANT, L. J. D. 1996. Positivismo. In : OUTHWAITE, W. \& BOTTOMORE, T. (orgs.). Dicionário do pensamento social do século $X X$. Rio de Janeiro : J. Zahar.

WEBER, M. 1977. A ciência como vocação. In : . Ciência e política - duas vocações. $7^{\mathrm{a}}$ ed. São Paulo : Cultrix. 


\section{AUGUSTE COMTE AND “POSITIVISM” REDISCOVERED}

Gustavo Biscaia de Lacerda

In this essay we look at some research that has, within the last ten years, revisited the work of Positivism's founder, Augusto Comte. This return to his work has consisted of perceiving his work in its entirety and through its own internal logic, placing particular emphasis on his second great work, Système de politique positive (1851-1854), and its contributions for contemporary political and social thought. In order to make the novelty of this new research clearer, we present one of the standard narratives on Comte and Positivism - in this case, through the work of Anthony Giddens ; we also go on to discuss the meaning of the term "Positivism" and the various theoretical currents that come together under this rubric.

Keywords: Positivism; theoretical interpretation; Augusto Comte; Anthony Giddens; Vienna Circle. 


\section{AUGUSTE COMTE ET LE “POSITIVISME” RÉDÉCOUVERTS}

\section{Gustavo Biscaia de Lacerda}

Dans cet essai nous abordons les recherches qui au cours des dix dernières années environ se sont penchées sur l'oeuvre du fondateur du Positivisme, Auguste Comte. Ce retour consiste à comprendre les travaux de Comte dans leur ampleur et à partir de leur logique interne, surtout en ce qui concerne son second ouvrage, le Système de politique positive (1851-1854), et ses contributions pour une réflexion sociale et politique contemporaine. Afin de rendre intelligible la réflexion des nouvelles recherches, nous présentons un des récits-standards concernant Comte et le Positivisme - en l'ocurrence, à partir des écrits d'Anthony Giddens - ; en outre, nous discutons du sens du mot «Positivisme» et des plusieurs courants théoriques sousjacents à cette expression.

MOTS-CLÉS : positivismes ; interprétation théorique ; Auguste Comte ; Anthony Giddens ; Cercle de Vienne. 